University of Nebraska - Lincoln

DigitalCommons@University of Nebraska - Lincoln

2013

\title{
Occurrence of antimicrobials and antimicrobial resistance genes in beef cattle storage ponds and swine treatment lagoons
}

\author{
Yuping Zhang \\ University of Nebraska-Lincoln \\ Chiqian Zhang \\ University of Nebraska-Lincoln \\ David B. Parker \\ USDA Meat Animal Research Center, david.parker@ars.usda.gov \\ Daniel D. Snow \\ University of Nebraska at Lincoln, dsnow1@unl.edu
}

Zhi Zhou

National University of Singapore, ceezz@nus.edu.sg

See next page for additional authors

Follow this and additional works at: https://digitalcommons.unl.edu/watercenterpubs

Part of the Environmental Indicators and Impact Assessment Commons, Fresh Water Studies

Commons, Hydraulic Engineering Commons, Hydrology Commons, Sustainability Commons, and the Water Resource Management Commons

Zhang, Yuping; Zhang, Chiqian; Parker, David B.; Snow, Daniel D.; Zhou, Zhi; and Li, Xu, "Occurrence of antimicrobials and antimicrobial resistance genes in beef cattle storage ponds and swine treatment lagoons" (2013). Faculty Publications from The Water Center. 25.

https://digitalcommons.unl.edu/watercenterpubs/25

This Article is brought to you for free and open access by the Water Center, The at DigitalCommons@University of Nebraska - Lincoln. It has been accepted for inclusion in Faculty Publications from The Water Center by an authorized administrator of DigitalCommons@University of Nebraska - Lincoln. 


\section{Authors}

Yuping Zhang, Chiqian Zhang, David B. Parker, Daniel D. Snow, Zhi Zhou, and Xu Li 


\title{
Occurrence of antimicrobials and antimicrobial resistance genes in beef cattle storage ponds and swine treatment lagoons
}

\author{
Yuping Zhang ${ }^{\mathrm{a}}$, Chiqian Zhang ${ }^{\mathrm{a}, 1}$, David B. Parker ${ }^{\mathrm{b}, 2}$, Daniel D. Snow ${ }^{\mathrm{c}}$, Zhi Zhou ${ }^{\mathrm{d}}, \mathrm{Xu} \mathrm{Li}^{\mathrm{a}, *}$ \\ a Department of Civil Engineering, University of Nebraska-Lincoln, Lincoln, NE, United States \\ ${ }^{\mathrm{b}}$ USDA Meat Animal Research Center, Clay Center, NE, United States \\ ' Water Sciences Laboratory, University of Nebraska-Lincoln, Lincoln, NE, United States \\ d Department of Civil and Environmental Engineering, National University of Singapore, Singapore
}

\section{H I G H L I G H T S}

- Partitioning of antimicrobials between water and sludge is compound specific.

- Antimicrobial resistance genes occurred in both water and sludge.

- The ARG abundance varied more substantially in swine lagoons than in cattle ponds.

- Correlations between ARGs and antimicrobials are system dependent.

\section{A R T I C L E I N F O}

\section{Article history:}

Received 10 April 2013

Received in revised form 5 June 2013

Accepted 5 June 2013

Available online $\mathrm{xxxx}$

Editor: Damia Barcelo

\section{Keywords:}

Antibiotic resistance gene

Antimicrobial

Lagoon

Storage pond

Tetracycline

Sulfonamide

\begin{abstract}
A B S T R A C T
Livestock manure treatment and storage structures are potential environmental sources of antimicrobials and antimicrobial resistance genes (ARGs). In this study, the occurrence of antimicrobials and ARGs was investigated in the water and the sludge compartments of beef cattle storage ponds and swine lagoons. Analysis was focused on two families of antimicrobials (sulfonamide and tetracycline) and the corresponding ARGs (sul1, sul2, tetO, tetQ and tetX). Results showed that the pseudo-partitioning coefficients of tetracyclines were higher than those of sulfonamides, suggesting different distributions of these two classes of antimicrobials between water and sludge. The ARGs tested were detected in nearly all ponds and lagoons, with the highest relative abundance in sul2 at $6.3 \times 10^{-1}$ copies per $16 \mathrm{~S}$ rRNA gene. A positive correlation was observed between total sul genes and total sulfonamides in water while the correlation was negative in sludge. No significant correlation was found between total tet genes and total tetracyclines in either water or sludge, but significant correlations were observed for certain individual tet genes. Ammonia concentrations strongly correlated with all ARGs except tetX. This study provided quantitative information on the occurrence of antimicrobials and ARGs in the liquid and solid compartments of typical manure treatment and storage structures.
\end{abstract}

(c) 2013 Elsevier B.V. All rights reserved.

\section{Introduction}

Antimicrobials are broadly used in the livestock industry to prevent and treat diseases and to promote growth. However, $17-80 \%$ of the antimicrobials administrated to animals are not adsorbed and are excreted through urine and feces (Halling-Sorensen et al., 1998; Montforts et al., 1999). Bacteria exposed to antimicrobials in the gut of animals may develop antimicrobial resistance (Sarmah et al., 2006). Antimicrobial

\footnotetext{
Abbreviation: ARG, Antibiotic resistance gene.

* Corresponding author at: 844 N. 16th Street, N117 SLNK, Lincoln, NE 68588-6105, United States. Tel.: +1 402472 6042; fax: +1 4024728934

E-mail address: xuli@unl.edu (X. Li).

1 Current address: Department of Civil and Environmental Engineering, University of Missouri-Columbia, Columbia, MO, United States.

${ }^{2}$ Current address: Palo Duro Research Center, West Texas A\&M University, Canyon, TX, United States.
}

resistance is conferred by antimicrobial resistance genes (ARGs), which usually reside on mobile genetic elements such as plasmids, integrons, and transposons (Allen et al., 2010). Because ARGs may be transferred to human pathogens, they are considered a class of contaminants with emerging concerns (Pruden et al., 2006; Shah et al., 2012).

Livestock facilities have been recognized as potential sources of antimicrobials and ARGs in the environment (Koike et al., 2007; Peak et al., 2007). Multiple classes of antimicrobials, including tetracyclines and sulfonamides, were detected in groundwater and surface water adjacent to swine and poultry farms (Campagnolo et al., 2002). In the river sediment downstream from livestock facilities, the concentrations of sulfonamide and tetracycline compounds were $3.5 \mu \mathrm{g} / \mathrm{L}$ and $86.4 \mu \mathrm{g} / \mathrm{L}$ during low-flow sampling events (Pei et al., 2006). In the same study, sulfonamide and tetracycline resistance genes (sul2 and tetW) were detected at the levels of $10^{-7}-10^{-5}$ copies per copy of the $16 \mathrm{~S}$ rRNA gene. Tetracycline resistance genes and erythromycin resistance genes 
were also repeatedly detected over a 3-year period in groundwater downstream of swine lagoons (Koike et al., 2007, 2010).

Storage ponds and treatment lagoons are commonly-used manure management structures at beef cattle and swine facilities. Similar to municipal wastewater treatment plants (Zhang et al., 2009), these manure management structures often contain high levels of antimicrobials and ARGs (Campagnolo et al., 2002; McKinney et al., 2010). In one study, nine antimicrobials were detected at concentrations that ranged between 0.62 and $32.67 \mu \mathrm{g} / \mathrm{L}$ in a swine lagoon in China (Ben et al., 2008). In another study, $1000 \mu \mathrm{g} / \mathrm{L}$ chlortetracycline, $400 \mu \mathrm{g} / \mathrm{L}$ sulfamethazine and $240 \mu \mathrm{g} / \mathrm{L}$ lincomycin, were reported in swine lagoon wastewaters in the U.S. (Campagnolo et al., 2002). Efforts were made to correlate the level of antimicrobials and that of the corresponding ARGs. Smith and colleagues detected an average of $1.95 \mu \mathrm{g} / \mathrm{L}$ tetracycline and approximately $10^{4}-10^{7}$ copies $/ \mathrm{mL}$ of total tetracycline resistance genes (tetO, tet $W$, and tetQ) in cattle feedlot lagoons (Smith et al., 2004). Peak and colleagues reported $0.45-16.40 \mu \mathrm{g} / \mathrm{L}$ tetracycline and $10^{3}-10^{6}$ copies/ $\mathrm{mL}$ of total tetracycline resistance genes (tet 0 , tet $\mathrm{Q}$ tetW, tetM, tetB and tetL) in cattle feedlot lagoons (Peak et al., 2007).

Most of the published studies were focused on either the water or the sludge compartment of waste management structures. However, it is important to investigate both compartments simultaneously because different antimicrobials behave differently in liquid-solid systems. For example, some antimicrobials tend to adsorb to solids, while others tend to occur in water (Sarmah et al., 2006). Furthermore, water and sludge in storage ponds and treatment lagoons are managed differently. Lagoon wastewater is often pumped out for irrigation at least once a year (Bodman, 1996), while lagoon sludge is removed every 5 to 20 years and land-applied to soil (Hamilton et al., 2006). Contents in storage ponds are removed every six months or more (Cooperative Extension System, 2008). Studies that investigate antimicrobials and ARGs in both the water and sludge of waste management structures are lacking in the literature.

The objective of this study was to investigate the occurrence of antimicrobials and ARGs in both the water and the sludge compartments of typical manure management structures and identify bulk water quality parameters that are potentially linked to the occurrence of ARGs. To achieve the objective, water and sludge samples were collected from four beef cattle storage ponds and three swine treatment lagoons. Sixteen antimicrobials, including members of the tetracycline, sulfonamide, and macrolide families, were quantified using liquid tandem mass spectrometry (LC-MS/MS). Multiple ARGs (i.e., sul1, sul2, tetO, tetQ and tetX) were measured using quantitative PCR (qPCR). Several routinely-used wastewater quality parameters were also measured and statistically analyzed to assess their correlation with ARGs.

\section{Materials and methods}

\subsection{Sampling and on site measurements}

Four sequential storage ponds holding manure wastes and runoff from a beef cattle feedlot ( $\mathrm{C} 1-\mathrm{C} 4)$ and three sequential swine wastewater treatment lagoons (S1-S3) at the USDA Meat Animal Research Center (Clay Center, NE) were included in this study (detailed description on the facilities can be found in Supporting information). Samples were collected in September 2010 and June 2011. Surface water samples were collected by submerging 1-L amber glass bottles (for chemical analyses) and 1-L polyethylene bottles (for microbial analyses) $\sim 10 \mathrm{~cm}$ below the water surface. If water was deeper than $1.2 \mathrm{~m}$ (Table S-1), a bottom water sample was collected $\sim 10 \mathrm{~cm}$ above the sediment to access the effect of stratification. Sludge samples were collected using an Ekman dredge sampler and then transferred to sterile plastic bags and amber jars. All water $(n=22)$ and sludge $(n=14)$ samples were collected from the center of the ponds and lagoons. Water temperature, $\mathrm{pH}$, dissolved oxygen (DO), oxidation-reduction potential (ORP) and electrical conductivity were measured on site using field probes (YSI
Professional Plus Multiparameter, Yellow Springs, OH). Samples were transported to the laboratory on ice within $6 \mathrm{~h}$ of collection. Subsamples were stored at $4{ }^{\circ} \mathrm{C}$ for routine chemical analyses and at $-20{ }^{\circ} \mathrm{C}$ for antimicrobial and DNA analyses.

\subsection{Water quality analysis}

The chemical oxygen demand (COD) of water samples was measured using high range COD digestion vials (Hach, Loveland, CO) according to the reactor digestion method (Jirka and Carter, 1975) which is approved by the US Environmental Protection Agency (EPA). Ammonia-nitrogen $\left(\mathrm{NH}_{3}-\mathrm{N}\right)$, nitrate/nitrite-nitrogen $\left(\mathrm{NO}_{2}^{-} / \mathrm{NO}_{3}^{-}-\mathrm{N}\right)$, and total phosphorus (TP) were measured using an AQ2 Automated Discrete Analyzer (Seal Analytical, Mequon, WI) according to EPA Method 350.1 (EPA, 1993b) and 365.1 (EPA, 1993c), respectively. Dissolved copper $(\mathrm{Cu})$ and zinc $(\mathrm{Zn})$ were measured using inductively coupled plasma-mass spectrometry (ICP-MS) (GV Instruments Ltd., Manchester, UK) according to EPA Method 6020A (EPA, 2007). Orthophosphate-phosphorous (ortho-P) and sulfate were measured using ion chromatography according to EPA Method 300.0 (EPA, 1993a). The removal efficiency of a contaminant in the sequential ponds or the sequential lagoons was defined based on the concentration difference between the first and the last pond/lagoon.

\subsection{Antimicrobial analysis}

Antimicrobial concentrations in water and sludge samples were analyzed using on-line LC-MS/MS with electrospray ionization (BarteltHunt et al., 2011; Snow et al., 2003). 0.5-5 mL of water sample was syringe-filtered ( $0.45 \mu \mathrm{m}$ Whatman glass fiber GDX), weighed directly into a $40-\mathrm{mL}$ vial, spiked with internal standards and surrogates, and thoroughly mixed with $20 \mathrm{~mL}$ reagent water and $500 \mu \mathrm{L} 2.4 \mathrm{M}$ citric acid. Analytes, internal standards and surrogates are listed in Table S-2. Calibration standards were prepared by fortifying $2.4 \mathrm{M}$ citric acid with analytes (10 to $1000 \mathrm{ng} / \mathrm{L}$ ) and treated in an identical manner as samples. During analysis each solution was extracted with a Spark Holland Symbiosis on-line solid extraction system using a Waters $(1 \times 2 \mathrm{~mm})$ HLB solid-phase extraction (SPE) cartridge and then eluted with mobile phase for subsequent separation and detection. Target analytes were detected in the mass spectrometer using SRM (selected reaction monitoring) MS/MS analysis on a Waters Quattro Micro triple quadrupole mass spectrometer. A Thermo HyPurity C18 $5 \mu \mathrm{m} 2 \times 250 \mathrm{~mm}$ column provided separation with a mobile phase comprised of 97:3 water/methanol and 3:97 methanol/water each containing $0.1 \%(\mathrm{v} / \mathrm{v}$ ) formic acid. LC-MS/MS conditions and transitions were determined and optimized by infusing with concentrated standards. A capillary voltage of $4.0 \mathrm{kV}$, an extractor of $3 \mathrm{~V}$ and an RF lens of $0.1 \mathrm{~V}$ were used. The source temperature was $120^{\circ} \mathrm{C}$ and the desolvation temperature was $500{ }^{\circ} \mathrm{C}$. The nebulizer flow rate was $700 \mathrm{~L} / \mathrm{h}$ in the desolvator and $30 \mathrm{~L} / \mathrm{h}$ in the cone.

Solid samples (1-5 gr) were weighed in $50 \mathrm{~mL}$ Teflon centrifuge tubes and mixed with $20 \mathrm{~mL}$ of $5 \mathrm{mmol}$ ammonium citrate/methanol $(\mathrm{pH}=6)$ loaded onto a Burrell Wrist-Action Shaker and equilibrated for $30 \mathrm{~min}$. The mixture was centrifuged for $10 \mathrm{~min}$ and the supernate decanted into a Labconco RapidVap ${ }^{\mathrm{TM}}$ evaporation tube. The process was repeated with $20 \mathrm{~mL}$ of citrate/methanol mixture followed by extraction with acetone. All extracts were combined, evaporated at $25{ }^{\circ} \mathrm{C}$ to approximately $20 \mathrm{~mL}$, mixed with reagent water to a final volume of $100 \mathrm{~mL}$, and cleaned using a $200 \mathrm{mg}$ Waters Oasis HLB SPE cartridge followed by elution with $2.5 \mathrm{~mL} 0.5 \%(\mathrm{v} / \mathrm{v})$ formic acid in methanol. Purified extracts were evaporated under nitrogen to a final volume of $200 \mu \mathrm{L}$, transferred to an autosampler insert, and then analyzed using similar conditions as the water samples using a $10 \mu \mathrm{L}$ injection volume. Chlortetracycline concentration includes isochlortetracycline, epichlortetracycline and chlortetracycline, while the tetracycline transition includes tetracycline and epitetracycline. 
To quantify the distribution of the antimicrobials between water and sludge, partitioning coefficient $\mathrm{K}_{\mathrm{d}}$ was used in this study and was calculated using the following equation (Midwood et al., 1998).

$\mathrm{K}_{\mathrm{d}}=\frac{\text { Concentration in sediment }(\mu \mathrm{g} / \mathrm{kg})}{\text { Concentration in water }(\mu \mathrm{g} / \mathrm{L})}$.

Since adsorption is not the only process that determined the antimicrobial distribution in these waste management structures, the calculated partitioning coefficient is termed pseudo-partitioning coefficient (Kim and Carlson, 2007).

\section{4. $q P C R$ standards}

Escherichia coli cultures containing various tet genes were obtained from Dr. Lisa Durso of the USDA Agricultural Research Service. Standards for sul genes were PCR-amplified from the activated sludge of a local wastewater treatment plant. Primer sequences and annealing temperatures for all regular PCR reactions are listed in Table S-3. PCR products were then cloned using an Invitrogen TOPO TA Cloning ${ }^{\circledR}$ Kit (Carlsbad, CA), and the plasmids were extracted and purified using a QIAGEN® Plasmid Kit (Valencia, CA). The plasmids containing sul genes were further confirmed by sequencing at Eurofins MWG Operon (Huntsville, AL). The copy number of genes in purified plasmid DNA was calculated as previously described (Pei et al., 2006), and the qPCR standards covered $10^{1}$ to $10^{9}$ copies $/ \mu \mathrm{L}$.

\subsection{DNA extraction and qPCR assays}

Cells in water samples were collected by centrifuging $50 \mathrm{~mL}$ of lagoon water at $5000 \times \mathrm{g}$ for $10 \mathrm{~min}$ at $4{ }^{\circ} \mathrm{C}$. DNA was then extracted from cell pellets or sludge samples using the FastDNA® SPIN Kit for Soil (MP Biomedicals, Solon, $\mathrm{OH}$ ) and was quantified using a NanoDrop 2000c Spectrophotometer (Thermo Fisher Scientific, Wilmington, $D E)$. qPCR was performed on a Mastercycler ep realplex thermocycler (Eppendorf, Hamburg, Germany). Each $20-\mu \mathrm{L}$ qPCR reaction contained $9 \mu \mathrm{L}$ of $2.5 \times$ RealMasterMix SYBR ROX (5 Prime; Gaithersburg, MD) and $4 \mathrm{ng}$ DNA. The final concentrations were $0.2 \mu \mathrm{M}$ of each primer for sul1, sul2, tetO and tetX, $0.25 \mu \mathrm{M}$ for tetD, $0.5 \mu \mathrm{M}$ for tetE and $0.4 \mu \mathrm{M}$ for tetQ. Primer sequences, annealing temperatures and references for qPCR on ARGs and the 16S rRNA gene are listed in Table S-4. All samples were quantified in duplicates. Sulfonamide ARGs sul1, sul2 and sul3 encode alternative variants of the DHPS enzymes, which are targets of sulfonamides (Skold, 2000). sul3 was not included in this study because it does not occur often in livestock wastes (Guerra et al., 2004; Sharma et al., 2008). Tetracycline resistance genes are categorized into three groups according to the resistance mechanism: efflux pump, ribosomal protection and enzymatic inactivation (Roberts, 2005). Representative tet genes from each category (tetD and tetE for efflux pumps, tet $O$ and tetQ for ribosomal protection, and tet $X$ for enzymatic inactivation) were selected in this study because of their occurrence in animal-related environments (Aminov et al., 2002; Patterson et al., 2007; Peak et al., 2007; Storteboom et al., 2010).

\subsection{Validation of DNA extraction and $q P C R$}

To assess the efficiencies of DNA extraction and PCR amplification, known amounts of $E$. coli cells containing individual ARGs were spiked into various types of samples, i.e., surface water in C1 (C1-S), bottom water in S2 (S2-B), sludge of B1 and S2 from first sampling event, following procedures reported by Koike et al. (2007). The DNA of pure E. coli, non-spiked samples and spiked samples was extracted as described above. qPCR was conducted and recovery was calculated as (ARG copy number in spiked sample - ARG copy number in nonspiked sample)/ARG copy number in the E. coli spiked.

\subsection{Data analysis}

All statistical tests were performed using R2.13.1 (R Foundation for Statistical Computing, Vienna, Austria). Statistical significance was defined as $p \leq 0.05$. Two tailed $t$-test was used to compare the difference between two groups, and Fisher's protected least significant difference (LSD) test was used to compare the differences among three or more groups. Correlation analysis was conducted using Pearson's correlation coefficient $(r)$, with $|r| \geq 0.5$ being considered strong, $0.5>|r|>0.3$ moderate and $|r| \leq 0.1$ weak (Cohen, 1988). Principal component analysis (PCA) was applied to ARG data.

\section{Results and discussion}

\subsection{Water quality analyses}

Water quality varied substantially between the cattle ponds and swine lagoons. The COD of the surface water in cattle ponds was generally higher than $1000 \mathrm{mg} / \mathrm{L}$, while that of the surface water in swine lagoons was usually less than $400 \mathrm{mg} / \mathrm{L}$ (Tables S-5 and S-6). The COD of the bottom water in swine lagoons was generally much higher than that of the surface water. The total phosphorus (TP) in cattle ponds was relatively constant in the two sampling events $(22.5 \pm 4.1 \mathrm{mg} / \mathrm{L}$ in Sep 2010 and $32.7 \pm 10.3 \mathrm{mg} / \mathrm{L}$ in Jun 2011). In contrast, the TP in swine lagoons increased from $14.0 \pm 5.4 \mathrm{mg} / \mathrm{L}$ in Sep 2010 to $33.8 \pm$ $18.8 \mathrm{mg} / \mathrm{L}$ in Jun 2011. The removal efficiencies for COD and TP were less than $15 \%$ in both the cattle pond series and the swine lagoon series in Sep 2010. The removal efficiencies for COD and TP were 13\% and 31\% in cattle ponds, and 59\% and 65\% in swine lagoons in Jun 2011. Ammonia-N was $<50 \mathrm{mg} / \mathrm{L}$ in cattle ponds but was generally $>70 \mathrm{mg} / \mathrm{L}$ in swine lagoons. Reduction in $\mathrm{NH}_{3}-\mathrm{N}$ was substantial in the sequential cattle ponds: 99\% removal in 2010 and 76\% in 2011 .

\subsection{Antimicrobial concentrations}

The occurrence of antimicrobials in the storage ponds and treatment lagoons was dependent on sample matrix (water vs. sludge) and animal type (cattle vs. swine). Samples were divided into four categories: cattle-water, cattle-sludge, swine-water, and swine-sludge. Among the 16 antimicrobials tested, all were detected in at least one water sample (Table S-7) and only 11 were detected in sludge samples (Table S-8). The five antimicrobials absent in sludge were erythromycin, sulfamethoxazole, sulfamethizole, sulfathiazole and virginiamycin. Furthermore, sulfamethoxazole, lincomycin and virginiamycin were not detected in either water or sludge of cattle ponds. Detection frequencies in water and sludge were similar for cattle ponds and swine lagoons (Table 1). Hence, results from cattle and swine were also combined to generate the detection frequencies in all water and all sludge samples (Table 1). With the exception of sulfamethazine, most sulfonamide compounds were detected more frequently in water than in sludge. Members of the tetracycline family (i.e., chlortetracycline, oxytetracycline, and tetracycline) were detected in all sludge samples, but only in $~ 40 \%$ of water samples. Among macrolides, erythromycin and tiamulin were detected more frequently in water, while tylosin was more likely to occur in the sludge. Among other antimicrobials tested, lincomycin had similar detection frequencies in water and sludge, while virginiamycin and monensin had higher detection frequency in water than in sludge. In the water compartment, the concentration of most antimicrobials in water was $\leq 4.9 \mu \mathrm{g} / \mathrm{L}$ except monensin, which ranged between 45.3 and $307.8 \mu \mathrm{g} / \mathrm{L}$ in cattle storage ponds (Table 1 ). In the sludge compartment, the concentration of sulfonamides was low $(\leq 6.3 \mu \mathrm{g} / \mathrm{kg})$, while tetracyclines in both cattle ponds and swine lagoons were high (6.2 to $7218.4 \mu \mathrm{g} / \mathrm{kg}$, Table 1 ).

Water and sludge in waste management treatment and storage structures are often handled differently. Irrigation with wastewater could potentially transport low- $\mathrm{K}_{\mathrm{d}}$ antimicrobials into soil and crops, 
Table 1

The detection frequency and ranges of antimicrobials in cattle storage ponds and swine treatment lagoons.

\begin{tabular}{|c|c|c|c|c|c|c|c|}
\hline & Antimicrobials & $\begin{array}{l}\text { Cattle-water } \\
(\mathrm{n}=10)\end{array}$ & $\begin{array}{l}\text { Cattle-sludge } \\
(\mathrm{n}=8)\end{array}$ & $\begin{array}{l}\text { Swine-water } \\
(\mathrm{n}=12)^{\mathrm{a}}\end{array}$ & $\begin{array}{l}\text { Swine-sludge } \\
(\mathrm{n}=6)\end{array}$ & $\begin{array}{l}\text { Water } \\
(\mathrm{n}=22)^{\mathrm{b}}\end{array}$ & $\begin{array}{l}\text { Sludge } \\
(\mathrm{n}=14)\end{array}$ \\
\hline \multirow[t]{3}{*}{ Tetracycline } & Chlortetracycline & $\begin{array}{l}40 \%^{\mathrm{c}} \\
(0.303-2.005)^{\mathrm{d}}\end{array}$ & $\begin{array}{l}100 \% \\
(34.4-1045.5)\end{array}$ & $\begin{array}{l}42 \% \\
(0.343-2.743)\end{array}$ & $\begin{array}{l}100 \% \\
(1089.9-7218.4)\end{array}$ & $41 \%$ & $100 \%$ \\
\hline & Oxytetracycline & $\begin{array}{l}10 \% \\
(1.471)\end{array}$ & $\begin{array}{l}100 \% \\
(1.9-24.6)\end{array}$ & $\begin{array}{l}33 \% \\
(0.010-3.138)\end{array}$ & $\begin{array}{l}100 \% \\
(7.7-65.6)\end{array}$ & $23 \%$ & $100 \%$ \\
\hline & Tetracycline & $\begin{array}{l}20 \% \\
(0.569-1.843)\end{array}$ & $\begin{array}{l}100 \% \\
(14.3-545.8)\end{array}$ & $\begin{array}{l}50 \% \\
(0.147-2.860)\end{array}$ & $\begin{array}{l}100 \% \\
(90.2-1623.8)\end{array}$ & $36 \%$ & $100 \%$ \\
\hline \multirow[t]{7}{*}{ Sulfonamide } & Sulfamethoxazole & $0 \%$ & $0 \%$ & $\begin{array}{l}42 \% \\
(0.104-0.342)\end{array}$ & $0 \%$ & $23 \%$ & $0 \%$ \\
\hline & Sulfamethazine & $\begin{array}{l}20 \% \\
(0.026-0.342)\end{array}$ & $\begin{array}{l}100 \% \\
(0.7-6.3)\end{array}$ & $\begin{array}{l}58 \% \\
(0.092-0.574)\end{array}$ & $\begin{array}{l}33 \% \\
(0.4)\end{array}$ & $41 \%$ & $71 \%$ \\
\hline & Sulfachloropyridazine & $\begin{array}{l}10 \% \\
(0.431)\end{array}$ & $\begin{array}{l}38 \% \\
(1.2-1.3)\end{array}$ & $\begin{array}{l}58 \% \\
(0.062-0.443)\end{array}$ & $0 \%$ & $36 \%$ & $21 \%$ \\
\hline & Sulfadimethoxine & $\begin{array}{l}90 \% \\
(0.027-0.586)\end{array}$ & $\begin{array}{l}88 \% \\
(0.5-3.4)\end{array}$ & $\begin{array}{l}50 \% \\
(0.179-0.548)\end{array}$ & $0 \%$ & $68 \%$ & $50 \%$ \\
\hline & Sulfamerazine & $0 \%$ & $\begin{array}{l}13 \% \\
(0.6)\end{array}$ & $\begin{array}{l}42 \% \\
(0.335-0.548)\end{array}$ & $\begin{array}{l}17 \% \\
(0.9)\end{array}$ & $23 \%$ & $14 \%$ \\
\hline & Sulfamethizole & $\begin{array}{l}10 \% \\
(0.452)\end{array}$ & $0 \%$ & $\begin{array}{l}50 \% \\
(0.213-0.490)\end{array}$ & $0 \%$ & $32 \%$ & $0 \%$ \\
\hline & Sulfathiazole & $\begin{array}{l}10 \% \\
(0.130)\end{array}$ & $0 \%$ & $\begin{array}{l}50 \% \\
(0.135-0.540)\end{array}$ & $0 \%$ & $32 \%$ & $0 \%$ \\
\hline \multirow[t]{3}{*}{ Macrolide } & Erythromycin & $\begin{array}{l}50 \% \\
(0.234-1.266)\end{array}$ & $0 \%$ & $\begin{array}{l}50 \% \\
(0.146-1.592)\end{array}$ & $0 \%$ & $50 \%$ & $0 \%$ \\
\hline & Tiamulin & $\begin{array}{l}70 \% \\
(0.012-0.455)\end{array}$ & $0 \%$ & $\begin{array}{l}58 \% \\
(0.138-3.636)\end{array}$ & $\begin{array}{l}100 \% \\
(1.2-26.5)\end{array}$ & $64 \%$ & $43 \%$ \\
\hline & Tylosin & $\begin{array}{l}10 \% \\
(0.040)\end{array}$ & $\begin{array}{l}50 \% \\
(0.5-0.8)\end{array}$ & $\begin{array}{l}42 \% \\
(0.505-4.913)\end{array}$ & $\begin{array}{l}100 \% \\
(4.0-170.4)\end{array}$ & $27 \%$ & $71 \%$ \\
\hline \multirow[t]{3}{*}{ Others } & Lincomycin & $0 \%$ & $0 \%$ & $\begin{array}{l}58 \% \\
(0.011-0.517)\end{array}$ & $\begin{array}{l}83 \% \\
(1.3-4.4)\end{array}$ & $32 \%$ & $36 \%$ \\
\hline & Virginiamycin & $0 \%$ & $0 \%$ & $\begin{array}{l}42 \% \\
(0.682-0.877)\end{array}$ & $0 \%$ & $23 \%$ & $0 \%$ \\
\hline & Monensin & $\begin{array}{l}90 \% \\
(45.300-307.800)\end{array}$ & $\begin{array}{l}100 \% \\
(6.2-297.1)\end{array}$ & $\begin{array}{l}100 \% \\
(0.705-0.895)\end{array}$ & $\begin{array}{l}50 \% \\
(2.7-17.5)\end{array}$ & $94 \%$ & $79 \%$ \\
\hline
\end{tabular}

\footnotetext{
a For monensin, $\mathrm{n}=6$.

b For monensin, $\mathrm{n}=16$.

c Percentages are detection frequency.

d Numbers in bracket are ranges of antimicrobial concentrations, in unit of $\mu \mathrm{g} / \mathrm{L}$ (water) or $\mu \mathrm{g} / \mathrm{kg}$ (sludge).
}

and may lead to contamination of these compounds or degradation products in surface and ground water through runoff and leaching (Sarmah et al., 2006). In comparison, the land application of sludge from storage ponds and treatment lagoons would provide a route of dissemination for highly-sorptive antimicrobials. In addition, the distribution of antimicrobials between water and sludge may also influence the degradation of these compounds. Biochemical and physiochemical degradations are often slower for compounds bound to particles than those dissolved in water due to lower availabilities (Doi and Stoskopf, 2000; Thiele-Bruhn, 2003; Watts, 1998). For instance, the half-life of oxytetracycline was 32 days in sediment, whereas it was as short as $128 \mathrm{~h}$ in seawater (Samuelsen, 1989). To our knowledge, this is one of the first studies to quantify antimicrobial concentrations in both water and sludge of manure management structures.
Partitioning of antimicrobials in liquid-solid systems depends on antimicrobials and adsorbents. The physicochemical properties of antimicrobials, such as molecular structure, size, shape, solubility, speciation, and hydrophobicity, are responsible for the difference (Sarmah et al., 2006). In addition, the partitioning of the same antimicrobial is affected by the properties of adsorbents. As shown in Table 2, the pseudo- $K_{d}$ values from this study were in better agreement with the $K_{d}$ values of soil than with the pseudo- $K_{d}$ values of river sediments. The difference among different adsorbents may be attributed to different organic carbon contents and particle sizes of the adsorbents.

Records show that around the time when samples were taken chlortetracycline, oxytetracycline and tylosin were administered in both livestock facilities, sulfadimethoxine was used on cattle only, and sulfachloropyridazine and lincomycin were used on swine only. All

Table 2

Partitioning coefficients $\left(\mathrm{K}_{\mathrm{d}}, \mathrm{kg} / \mathrm{L}\right)$ and pseudo partitioning coefficients (pseudo $\mathrm{K}_{\mathrm{d}}, \mathrm{kg} / \mathrm{L}$ ) of antimicrobials in different liquid-solid systems.

\begin{tabular}{|c|c|c|c|c|}
\hline \multirow[t]{2}{*}{ Antimicrobials } & \multicolumn{2}{|c|}{ Pseudo $K_{d}$ in this study (sludge as adsorbent) } & \multirow{2}{*}{$\begin{array}{l}\mathrm{K}_{\mathrm{d}} \text { (soil as adsorbent) } \\
\text { (Sarmah et al., 2006) }\end{array}$} & \multirow{2}{*}{$\begin{array}{l}\text { Pseudo } K_{d} \\
\text { (river sediment as adsorbent) } \\
\text { (Kim and Carlson, 2007) }\end{array}$} \\
\hline & Median & $95 \% \mathrm{CI}$ & & \\
\hline Chlortetracycline & 2069.0 & $120.7-4973.4(\mathrm{n}=7)$ & $1280-2386$ & 305 \\
\hline Oxytetracycline & 25 & $0-662.0(\mathrm{n}=4)$ & 417-1026 & 1267 \\
\hline Tetracycline & 489.1 & $14-1018.4(\mathrm{n}=6)$ & $1147-2370$ & 1051 \\
\hline Sulfamethazine & 1.6 & $0-21.2(\mathrm{n}=5)$ & $0.6-3.2$ & 517 \\
\hline Sulfadimethoxine & 12.2 & $0-55.6(n=6)$ & $2.3-4.6$ & 402 \\
\hline Tiamulin & 8.4 & $0-98.0(\mathrm{n}=5)$ & & \\
\hline Tylosin & 32.4 & $0-202.5(n=7)$ & $8.3-128$ & 91 \\
\hline Lincomycin & 55.3 & $0-1757.0(n=4)$ & & \\
\hline Monensin & 1.4 & $0-9.6(\mathrm{n}=10)$ & $1.09-78.6$ & \\
\hline
\end{tabular}


antimicrobials were administrated through injection except that chlortetracycline was also added to feeds when animals were sick. In general, these antimicrobials had higher detection frequency than the other antimicrobials measured. Some antimicrobials, such as tetracycline, tiamulin, and monensin, were not administered to the animals at the time of sampling. However, they were frequently detected in the cattle ponds and/or swine lagoons (Table 1), likely as a result of accumulation from previous usage on the animals.

\subsection{Validation of $q P C R$ assays}

One sul gene and three tet genes were selected to assess the efficiencies of DNA extraction and qPCR amplification in different sample types. The four selected ARGs covered various resistance mechanisms against these two classes of antimicrobials. Details of qPCR assay validation results are listed in Table S-9. The recovery was gene-specific, and within each gene the variance among samples was small. For example, the recovery rate for sul 2 was $76.6 \pm 10.5 \%$ and that for tet $Q$ was $87.4 \pm 16.1 \%$. The recovery rates for the other two ARGs were higher than $100 \%$ : $149.8 \pm 43.7 \%$ for tetD and $321.7 \pm 63.8 \%$ for tetX. A wide range of qPCR recovery rates is not uncommon among lagoon samples: one study reported $17.7-166.3 \%$ for 7 tet genes (Koike et al., 2007) and another study reported 33-400\% for sul and tet genes (suppression factor, inverse of recovery rate, was reported in the latter study) (McKinney et al., 2010).

\subsection{Quantification of ARGs}

All ARG values in this work were calculated by normalizing the ARG concentration to the 16S rRNA gene concentration, an approximation of the relative abundance of the antimicrobial resistant population in bacterial communities. Because tetD and tetE only occurred in a few samples (data not shown), these two ARGs were not included in further analyses. The average relative abundance of ARGs ranged from $5.5 \times 10^{-6}$ to $6.3 \times 10^{-1}$ copies per $16 \mathrm{~S}$ rRNA gene (Fig. 1 ). Swine lagoons usually had higher relative abundance of ARGs than cattle ponds, although for tetQ and tetX the difference was not statistically significant (Figs. S-1 and S-2). The first two principal components (PC1 and PC2) in the PCA analysis accounted for $85.2 \%$ and $90.5 \%$ of the total ARG data variance in the water and sludge compartments, respectively, of livestock waste management structures (Fig. 2). Data representing ARGs in cattle ponds clustered together, showing that the relative abundance of ARGs in cattle waste storage ponds was relatively constant at the two sampling times. In contrast, data representing ARGs in swine lagoons are more scattered, suggesting that the relative abundance of ARGs varied among lagoons and with time (Fig. 2).

Due to the highly sorptive nature, tetracyclines accumulated more in sludge than in water. This distribution could presumably lead to higher selective pressure, and consequently highly relative abundance of tet genes in sludge than in water. However, the relative abundance of tet genes was similar in the water and sludge compartments in both the cattle ponds and the swine lagoons (Fig. 3). In contrast, the sulfonamide compounds were more evenly distributed between water and sludge, and relative abundance of sul genes was significantly higher in water than in sludge (Fig. 3). These distributions suggest that the aqueous antimicrobials may be more biologically available than adsorbed antimicrobials.

Although overall the relative abundance of ARGs in sludge was lower than that in water, since the bacteria density in sludge was higher than that in water (according to the abundance of the 16S rRNA gene, data not shown), the absolute abundance of ARGs is calculated to be 1 to 5 orders of magnitude higher in sludge (copies/g sludge) than in water (copies/mL water). Finally, the surface water and bottom water in swine lagoons were not significantly different in terms of the relative abundance of ARGs (Fig. 3), suggesting that the distribution of antimicrobial resistant bacteria might not be affected by the vertical profiles of certain water quality factors, such as DO.

\subsection{Correlations}

Pearson's correlation coefficients and $p$-values between ARGs and water constituents are tabulated in Table 3. Ammonia showed a strong and positive correlation with all ARGs except tetX. Copper exhibited moderate negative correlation with $\mathrm{sul}^{R}$, tetO and tetQ. Other correlations between ARGs and water parameters were either insignificant or involved with only one ARG.

Correlation between $\mathrm{NH}_{3}-\mathrm{N}$ and ARGs has been previously reported. Mckinney and co-workers studied the ARGs in various livestock lagoon systems, and found strong correlations between $\mathrm{NH}_{3}-\mathrm{N}$ and tetracycline resistance genes (McKinney et al., 2010). The authors further suggested that lagoons capable of improving water quality could also effectively remove ARGs and recommended $\mathrm{NH}_{3}-\mathrm{N}$ as a potential indicator for the occurrence of ARGs in livestock lagoons (McKinney et al., 2010). Further studies are needed to explain the correlation between $\mathrm{NH}_{3}-\mathrm{N}$ and ARGs.
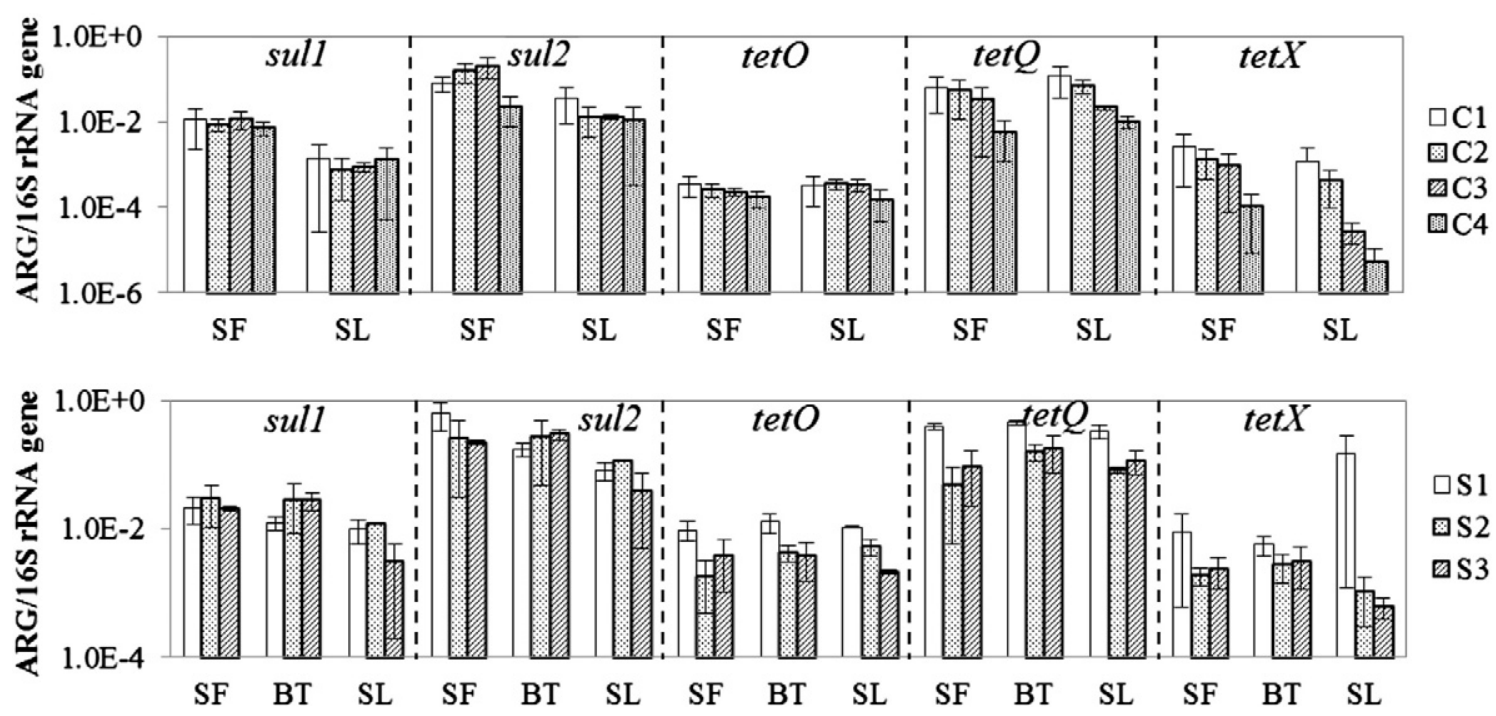

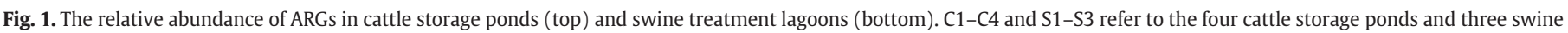
treatment lagoons sampled in this study. Error bars represent the half-range of the two sampling events. SF $=$ surface water, BT $=$ bottom water, SL $=$ sludge. 

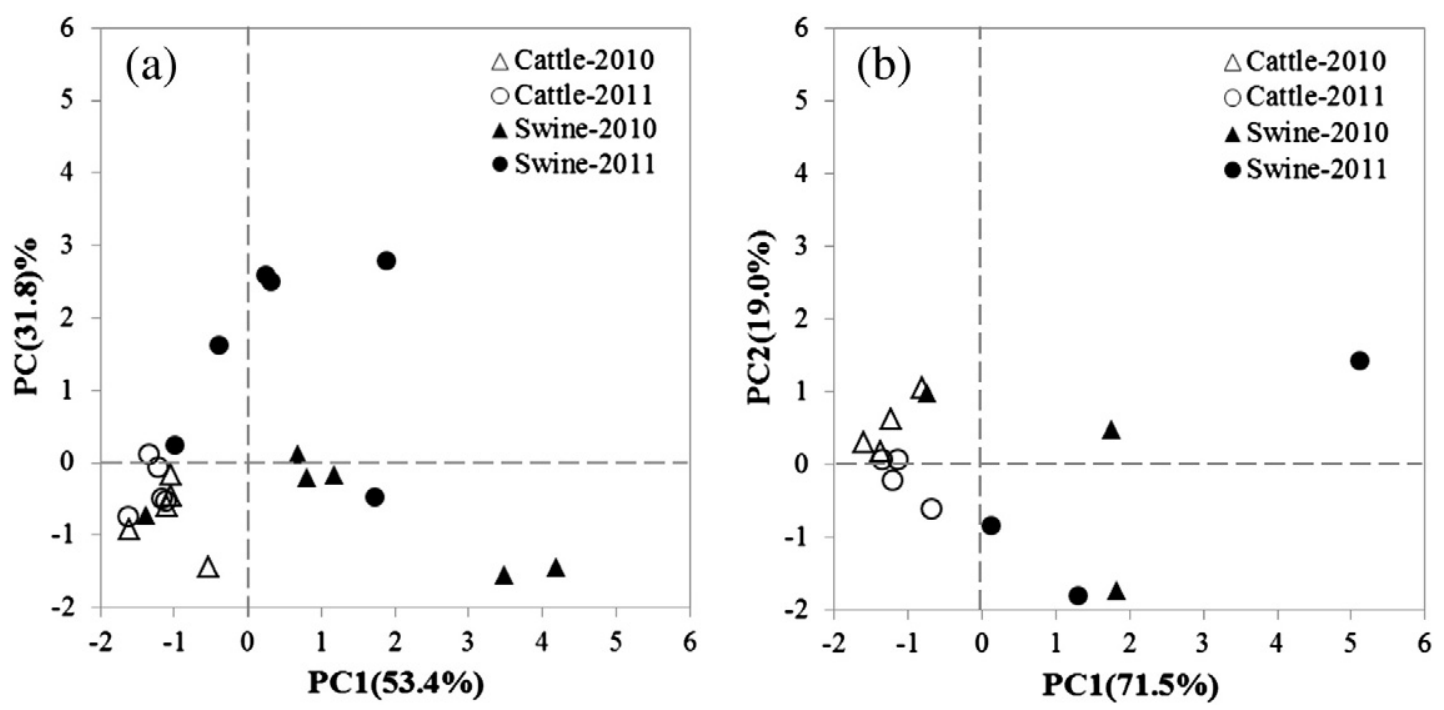

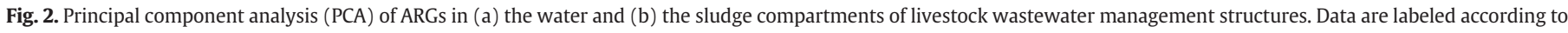
livestock facilities and sampling time.

Copper and zinc can induce antimicrobial resistance, as the resistance to these metals and resistance to antimicrobials are often co-selected (Baker-Austin et al., 2006; Wardwell et al., 2009). Cu and $\mathrm{Zn}$ are often added in swine feed as growth promoters (Hill et al., 2000). In this study, Cu and $\mathrm{Zn}$ were detected at low levels in water $(<0.065 \mathrm{mg} / \mathrm{L}$, Tables S-5 and S-6). No significant positive correlation was observed between $\mathrm{Zn} / \mathrm{Cu}$ and the ARGs tested, likely because the levels of soluble $\mathrm{Zn}$ and $\mathrm{Cu}$ were low and did not exert sufficient pressure on microorganisms. An amount of $1.04 \mathrm{mg} / \mathrm{L} \mathrm{Zn}$ was reportedly required to induce resistance to $\mathrm{Zn}$ and $2.56 \mathrm{mg} / \mathrm{L}$ $\mathrm{Cu}$ was required to induce resistance to $\mathrm{Cu}$ in E. coli (Nies, 1992; Rouch et al., 1985). Mckinney et al. found positive correlations between tetO/tetW and $\mathrm{Cu}$ when the concentration of $\mathrm{Cu}$ was as high as $103 \mathrm{mg} / \mathrm{L}$ (McKinney et al., 2010).

In addition to the correlation with water constituents, the correlation between ARGs and antimicrobials was also analyzed (Table 4). A positive correlation was observed between sul2/sul ${ }^{R}$ and total sulfonamide (including the 7 sulfonamide compounds listed in Table 1) in water but the correlation became negative in sludge. For tetracycline resistance genes, tet $X$ and tet $O$ exhibited strong, positive correlations with the total tetracycline (including chlortetracycline, oxytetracycline and tetracycline) in water and sludge, respectively. Correlations between ARGs and individual tetracycline and sulfonamide compounds plus other antimicrobials tested were also analyzed and the coefficients and $p$-values were tabulated in Tables S-10 and S-11. Some significant positive correlations include the ones between lincomycin and sul2/tetO/tetX in water and the ones between tiamulin/ tylosin and all ARGs in sludge.

Previous studies have suggested a link between the occurrence of antimicrobials and increasing antimicrobial resistance in the environment (Luo et al., 2010; Peak et al., 2007; Pei et al., 2006). However, the correlation, or sometimes the lack of correlation, between antimicrobials and ARGs is usually system dependent. In a cattle feedlot wastewater holding pond, the tet ${ }^{R}$ (tetO, tetQ and tetW) level was 4- to 8.3-fold higher in water samples containing $>1.95 \mu \mathrm{g} / \mathrm{L}$ tetracycline than in those containing $<1.95 \mu \mathrm{g} / \mathrm{L}$ tetracycline (Smith et al., 2004). In a wastewater
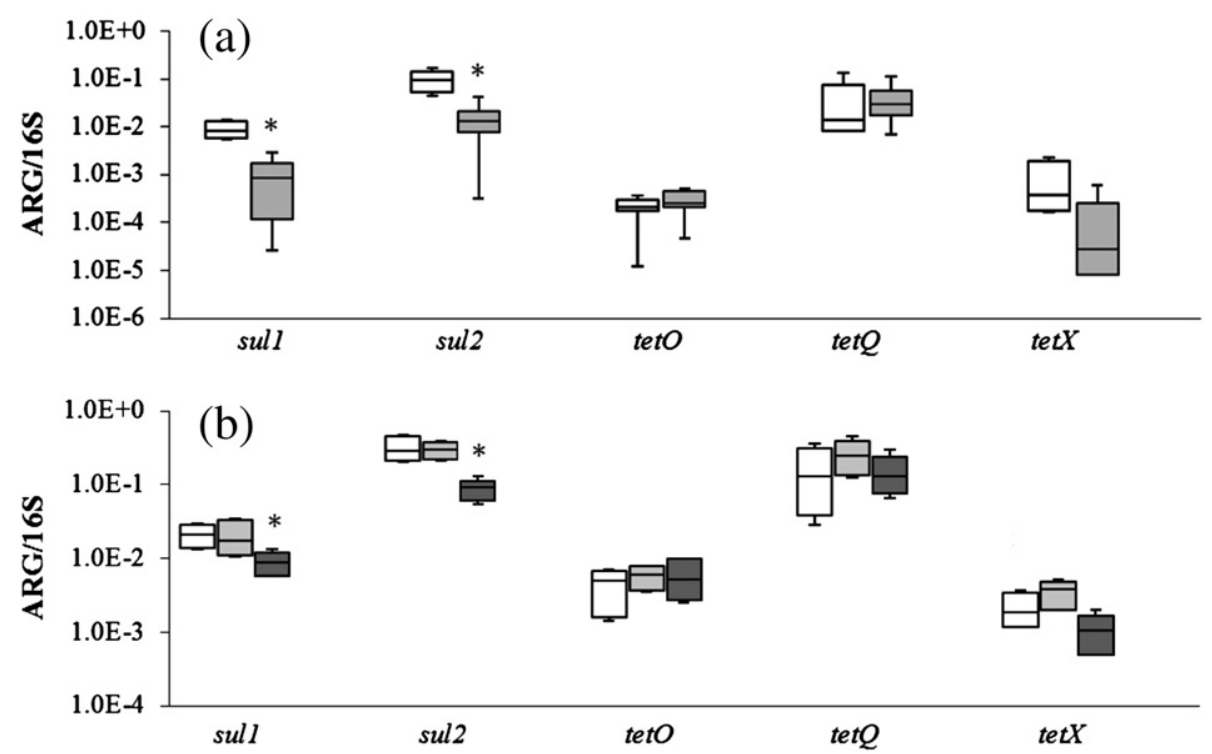

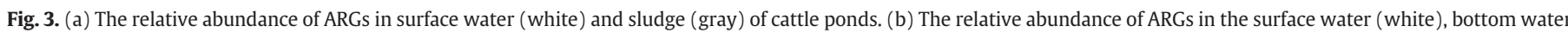
(light gray), and sludge (dark gray) of swine lagoons. Significant difference is marked as “*”. 
Table 3

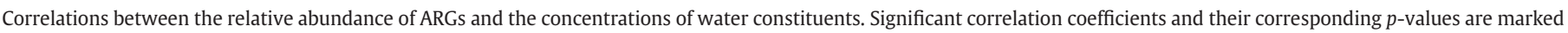
with underlines.

\begin{tabular}{|c|c|c|c|c|c|c|c|c|c|c|}
\hline & \multicolumn{2}{|l|}{ sul1 } & \multicolumn{2}{|l|}{ sul2 } & \multicolumn{2}{|l|}{ tetO } & \multicolumn{2}{|l|}{ tetQ } & \multicolumn{2}{|l|}{ tetX } \\
\hline & $r$ & p-Value & $r$ & $p$-Value & $r$ & $p$-Value & $r$ & $p$-Value & $r$ & $p$-Value \\
\hline COD & -0.36 & 0.098 & -0.38 & 0.083 & 0.38 & 0.077 & 0.43 & 0.045 & 0.05 & 0.813 \\
\hline $\mathrm{NH}_{4}^{+}-\mathrm{N}$ & 0.58 & 0.005 & 0.60 & 0.003 & 0.69 & $<0.001$ & $\overline{0.73}$ & $<\overline{\mathbf{0 . 0 0 1}}$ & 0.39 & 0.073 \\
\hline $\mathrm{TP}$ & $\overline{0.15}$ & $\overline{0.518}$ & $\overline{0.28}$ & $\overline{0.208}$ & $-\overline{0.04}$ & $\overline{0.847}$ & $\overline{0.16}$ & $\overline{0.481}$ & -0.39 & 0.076 \\
\hline Ortho-P & -0.35 & 0.112 & -0.52 & 0.014 & -0.37 & 0.086 & -0.34 & 0.124 & -0.31 & 0.155 \\
\hline $\mathrm{SO}_{4}^{2-}$ & -0.36 & 0.103 & $\overline{-0.14}$ & $\overline{0.520}$ & -0.15 & 0.518 & -0.09 & 0.676 & 0.18 & 0.410 \\
\hline $\mathrm{Zn}$ & -0.36 & 0.095 & -0.53 & 0.012 & -0.24 & 0.276 & -0.17 & 0.455 & -0.26 & 0.244 \\
\hline $\mathrm{Cu}$ & -0.49 & 0.020 & $\overline{-0.48}$ & $\overline{0.024}$ & -0.52 & 0.013 & -0.43 & 0.047 & -0.21 & 0.343 \\
\hline
\end{tabular}

treatment plant (WWPT) effluent, the absolute abundance of tetO and tetW showed no significant correlation with the total tetracycline (i.e., oxytetracycline, doxycycline, chlortetracycline and tetracycline) concentration, which was lower than $1.1 \mu \mathrm{g} / \mathrm{L}$ (Gao et al., 2012). In this study, with the total tetracycline less than $7.74 \mu \mathrm{g} / \mathrm{L}$ in water, no significant correlation was seen between $t e t^{R}$ and tetracyclines (Table 4). One possible explanation for the inconsistency on correlation is that there is a concentration threshold for antimicrobials to effectively exert selective pressure for ARGs (Smith et al., 2004). In a laboratory experiment, it was found that at least $20 \mu \mathrm{g} / \mathrm{L}$ of oxytetracycline was needed to cause an increase in the relative abundance of tet ${ }^{R}$ (tetB, tetL, tetM, tetO, tetQ and tetW) in mesocosms derived from pristine surface water (Knapp et al., 2008).

Similar to the correlation in water, the correlation between ARGs and antimicrobials in sludge also depends on the system. For example, there was no significant correlation between $t e t^{R}$ and tetracycline (701-1150 $\mu \mathrm{g} / \mathrm{kg}$ ) or between $s u l^{R}$ and sulfonamide (76-113 $\mu \mathrm{g} / \mathrm{kg}$ ) in municipal wastewater samples (Gao et al., 2012). In contrast, the correlations between $s u l^{R}$ and sulfonamide (from $<5$ to $840 \mu \mathrm{g} / \mathrm{kg}$ ) and between $t^{R} t^{R}$ and tetracycline (from $<5$ to $>3000 \mu \mathrm{g} / \mathrm{kg}$ ) were significant in lagoon sediment (McKinney et al., 2010).

In addition to the concentration threshold requirement, other factors may also contribute to the lack of consistent correlation between ARGs and antimicrobials. Studies show that ARGs may persist in bacteria even after the antimicrobials in the environment have diminished, known as the "easy-to-get, hard-to-lose" phenomenon (Aminov and Mackie, 2007; Salyers and Amabile-Cuevas, 1997). Also, antimicrobials could co-select certain ARGs, as often suggested by the co-existence of several ARGs (Chung et al., 1999; Salyers et al., 1995; Speer et al., 1991b). For instance, sul1 and tet $G$ were located on the same plasmid (Ng et al., 1999), tetracycline resistance genes tetQ and tetX co-existed with tylosin resistance gene ermF on conjugative transposons (Chung et al., 1999; Speer et al., 1991a), and tetM and another tylosin resistance gene ermB were located on the same conjugative transposon (Clewell et al., 1995). It is noticed that in this study there was a strong positive correlation between tetracycline resistance genes and macrolides (tetO/tetQ/tetX vs. tiamulin/tylosin, Table S-11).

Table 4

Correlation between the relative abundance of ARGs and the concentrations of the corresponding antimicrobials.

\begin{tabular}{|c|c|c|c|c|}
\hline & \multicolumn{2}{|c|}{ Water } & \multicolumn{2}{|l|}{ Sludge } \\
\hline & $r$ & $p$-Value & $r$ & $p$-Value \\
\hline sul1 - total sulfonamide & 0.22 & 0.329 & -0.52 & 0.057 \\
\hline sul2 - total sulfonamide & 0.45 & 0.036 & -0.56 & 0.035 \\
\hline$s u l^{R a}$ - total sulfonamide & $\overline{0.50}$ & $\overline{0.035}$ & $\overline{-0.56}$ & $\overline{0.037}$ \\
\hline tetO - total tetracycline & $\overline{0.36}$ & $\overline{0.104}$ & 0.84 & $<\overline{\mathbf{0 . 0 0 1}}$ \\
\hline tetQ - total tetracycline & 0.36 & 0.099 & $\overline{0.50}$ & $\overline{0.068}$ \\
\hline tetX - total tetracycline & 0.61 & 0.003 & 0.11 & 0.699 \\
\hline tet $^{R \mathrm{~b}}-$ total tetracycline & $\overline{0.37}$ & $\overline{0.269}$ & 0.38 & 0.183 \\
\hline
\end{tabular}

\section{Conclusions}

In summary, antimicrobials and ARGs were quantified for the water and the sludge compartments of the waste management structures in two livestock facilities. The partitioning of the antimicrobials between water and sludge was compound specific. ARGs occurred in both water and sludge compartments, and its abundance varied more substantially in swine lagoons than in cattle ponds. The correlation between ARGs and antimicrobials is system dependent. This is one of the first studies that investigate the distributions of antimicrobials and ARGs between water and sludge in livestock waste management structures. This information is useful in developing management strategies to minimize the spread of antimicrobials and ARGs when water is discharged and sludge is land applied.

\section{Disclaimer}

Mention of trade names or commercial products in this article is solely for the purpose of providing specific information and does not imply recommendation or endorsement by the USDA. USDA is an equal opportunity provider and employer.

\section{Acknowledgment}

We would like to thank Bryan Woodbury and Zhongtian Li for helping with sampling. This research was financially supported by the USGS 104b program.

\section{Appendix A. Supplementary data}

Supplementary data to this article can be found online at http:// dx.doi.org/10.1016/j.scitotenv.2013.06.016.

\section{References}

Allen H, Donato J, Wang H, Cloud-Hansen K, Davies J, Handelsman J. Call of the wild: antibiotic resistance genes in natural environments. Nat Rev Microbiol 2010;8: 251-9.

Aminov RI, Mackie RI. Evolution and ecology of antibiotic resistance genes. FEMS Microbiol Lett 2007;271:147-61.

Aminov R, Chee-Sanford J, Garrigues N, Teferedegne B, Krapac I, White B, et al. Development, validation, and application of PCR primers for detection of tetracycline efflux genes of gram-negative bacteria. Appl Environ Microbiol 2002:1786-93.

Baker-Austin C, Wright M, Stepanauskas R, McArthur J. Co-selection of antibiotic and metal resistance. Trends Microbiol 2006:176-82.

Bartelt-Hunt S, Snow DD, Damon-Powell T, Miesbach D. Occurrence of steroid hormones and antibiotics in shallow groundwater impacted by livestock waste control facilities. J Contam Hydrol 2011;123:94-103.

Ben W, Qiang Z, Adams C, Zhang H, Chen L. Simultaneous determination of sulfonamides, tetracyclines and tiamulin in swine wastewater by solid-phase extraction and liquid chromatography-mass spectrometry. J Chromatogr 2008;1202:173-80.

Bodman GR. EC96-779 lagoons for management of livestock manure. Historical materials from University of Nebraska-Lincoln Extension; 1996. p. 1646.

Campagnolo E, Johnson K, Karpati A, Rubin C, Kolpin D, Meyer M, et al. Antimicrobial residues in animal waste and water resources proximal to large-scale swine and poultry feeding operations. Sci Total Environ 2002;299:89-95. 
Chung WO, Young K, Leng ZT, Roberts MC. Mobile elements carrying ermF and tetQ genes in Gram-positive and Gram-negative bacteria. J Antimicrob Chemother 1999;44: 329-35.

Clewell DB, Flannagan SE, Jaworski DD. Unconstrained bacterial promiscuity: the Tn916-Tn1545 family of conjugative transposons. Trends Microbiol 1995;3:229.

Cohen J. Statistical power analysis for the behavioral sciences. Lawrence Erlbaum; 1988.

Cooperative Extension System. What is the difference between a storage pond and a lagoon for handling animal wastewater/manure. 2012. eXtension; 2008.

Doi A, Stoskopf M. The kinetics of oxytetracycline degradation in deionized water under varying temperature, $\mathrm{pH}$, light, substrate, and organic matter. J Aquat Anim Health 2000; $12: 246-53$

EPA. Method 300.0: determination of inorganic anions by ion chromatography; 1993a.

EPA. Method 350.1: determination of ammonia nitrogen by semi-automated colorimetry, Cincinnati, Ohio; 1993b.

EPA. Method 365.1: determination of phosphorus by semi-automated colorimetry, Cincinnati, Ohio; 1993c.

EPA. Method 6020A, inductively coupled plasma-mass spectrometry; 2007.

Gao P, Munir M, Xagoraraki I. Correlation of tetracycline and sulfonamide antibiotics with corresponding resistance genes and resistant bacteria in a conventional municipal wastewater treatment plant. Sci Total Environ 2012;421:173-83.

Guerra B, Junker E, Helmuth R. Incidence of the recently described sulfonamide resistance gene sul3 among German Salmonella enterica strains isolated from livestock and food. Antimicrob Agents Chemother 2004;48:2712-5.

Halling-Sorensen B, Nielsen S, Lanzky P, Ingerslev F, Lutzhoft H, Jorgensen S. Occurrence, fate and effects of pharmaceutical substances in the environment - a review. Chemosphere 1998;36:357-94.

Hamilton DW, Fathepure B, Fuhage CD, Clarkson W, Laiman J. Treatment lagoons for animal agriculture. Animal agriculture and the environment: National Center for Manure and Animal Waste Management White Papers; 2006547-74.

Hill G, Cromwell G, Crenshaw T, Dove C, Ewan R, Knabe D, et al. Growth promotion effects and plasma changes from feeding high dietary concentrations of zinc and copper to weanling pigs (regional study). J Anim Sci 2000;78:1010-6.

Jirka AM, Carter MJ. Micro semiautomated analysis of surface and waste waters for chemical oxygen demand. Anal Chem 1975;47:1397-402.

Kim S, Carlson K. Temporal and spatial trends in the occurrence of human and veterinary antibiotics in aqueous and river sediment matrices. Environ Sci Technol 2007: 50-7.

Knapp C, Engemann C, Hanson M, Keen P, Hall K, Graham D. Indirect evidence of transposon-mediated selection of antibiotic resistance genes in aquatic systems at low-level oxytetracycline exposures. Environ Sci Technol 2008:5348-53.

Koike S, Krapac I, Oliver H, Yannarell A, Chee-Sanford J, Aminov R, et al. Monitoring and source tracking of tetracycline resistance genes in lagoons and groundwater adjacent to swine production facilities over a 3-year period. Appl Environ Microbiol 2007:4813-23.

Koike S, Aminov RI, Yannarell AC, Gans HD, Krapac IG, Chee-Sanford JC, et al. Molecular ecology of macrolide-lincosamide-streptogramin B methylases in waste lagoons and subsurface waters associated with swine production. Microb Ecol 2010;59: 487-98.

Luo Y, Mao D, Rysz M, Zhou Q, Zhang H, Xu L, et al. Trends in antibiotic resistance genes occurrence in the Haihe River, China. Environ Sci Technol 2010;44:7220-5.

McKinney C, Loftin K, Meyer M, Davis J, Pruden A. tet and sul antibiotic resistance genes in livestock lagoons of various operation type, configuration, and antibiotic occurrence. Environ Sci Technol 2010:6102-9.

Midwood AJ, Boutton TW, Archer SR, Watts SE. Water use by woody plants on contrasting soils in a savanna parkland: assessment with $\delta 2 \mathrm{H}$ and $\delta 180$. Plant Soil 1998;205: $13-24$.

Montforts M, Kalf D, van Vlaardingen P, Linders J. The exposure assessment for veterinary medicinal products. Sci Total Environ 1999;225:119-33.

Ng L, Mulvey M, Martin I, Peters G, Johnson W. Genetic characterization of antimicrobial resistance in Canadian isolates of Salmonella serovar typhimurium DT104. Antimicrob Agents Chemother 1999;43:3018-21.
Nies D. CzcR Aand CzcD, gene-products affecting regulation of resistance to cobalt, zinc, and cadmium (Czc system) in Alcaligenes eutrophus. J Bacteriol 1992;174:8102-10.

Patterson A, Colangeli R, Spigaglia P, Scott K. Distribution of specific tetracycline and erythromycin resistance genes in environmental samples assessed by macroarray detection. Environ Microbiol 2007;9:703-15.

Peak N, Knapp C, Yang R, Hanfelt M, Smith M, Aga D, et al. Abundance of six tetracycline resistance genes in wastewater lagoons at cattle feedlots with different antibiotic use strategies. Environ Microbiol 2007:143-51.

Pei R, Kim S, Carlson K, Pruden A. Effect of river landscape on the sediment concentrations of antibiotics and corresponding antibiotic resistance genes (ARG). Water Res 2006;40:2427-35.

Pruden A, Pei R, Storteboom H, Carlson K. Antibiotic resistance genes as emerging contaminants: studies in northern Colorado. Environ Sci Technol 2006;40:7445-50.

Roberts M. Update on acquired tetracycline resistance genes. FEMS Microbiol Lett 2005:245:195-203.

Rouch D, Camakaris J, Lee B, Luke R. Inducible plasmid-mediated copper resistance in Escherichia coli. J Gen Microbiol 1985;131:939-43.

Salyers AA, Amabile-Cuevas CF. Why are antibiotic resistance genes so resistant to elimination? Antimicrob Agents Chemother 1997;41:2321.

Salyers A, Shoemaker N, Stevens A, Li L. Conjugative transposons-an unusual and diverse set of integrated gene-transfer elements. Microbiol Rev 1995;59:579-\&.

Samuelsen OB. Degradation of oxytetracycline in seawater at two different temperatures and light intensities, and the persistence of oxytetracycline in the sediment from a fish farm. Aquaculture 1989;83:7-16.

Sarmah A, Meyer M, Boxall A. A global perspective on the use, sales, exposure pathways, occurrence, fate and effects of veterinary antibiotics (VAs) in the environment Chemosphere 2006:725-59.

Shah SQA, Colquhoun DJ, Nikuli HL, Sorum H. Prevalence of antibiotic resistance genes in the bacterial flora of integrated fish farming environments of Pakistan and Tanzania. Environ Sci Technol 2012;46:8672-9.

Sharma R, Munns K, Alexander T, Entz T, Mirzaagha P, Yanke LJ, et al. Diversity and distribution of commensal fecal Escherichia coli bacteria in beef cattle administered selected subtherapeutic antimicrobials in a feedlot setting. Appl Environ Microbiol 2008;74:6178-86.

Skold O. Sulfonamide resistance: mechanisms and trends. Drug Resist Updat 2000;3: 155-60.

Smith M, Yang R, Knapp C, Niu Y, Peak N, Hanfelt M, et al. Quantification of tetracycline resistance genes in feedlot lagoons by real-time PCR. Appl Environ Microbiol 2004: 7372-7.

Snow DD, Cassada DA, Monson SJ, Zhu J, Spalding RF. Tetracycline and macrolide antibiotics: trace analysis in water and wastewater using solid phase extraction and liquid chromatography-tandem mass spectrometry. ACS symposium series, 850 Washington, DC: American Chemical Society; 1999, 2003. p. 161-74.

Speer B, Bedzyk L, Salyers A. Evidence that a novel tetracycline resistance gene found on 2 Bacteroides transposons encodes an NADP-requiring oxidoreductase. J Bacterio 1991a;173:176-83.

Speer BS, Bedzyk L, Salyers AA. Evidence that a novel tetracycline resistance gene found on two Bacteroides transposons encodes an NADP-requiring oxidoreductase. J Bacteriol 1991b;173:176-83.

Storteboom H, Arabi M, Davis J, Crimi B, Pruden A. Identification of antibiotic-resistancegene molecular signatures suitable as tracers of Pristine River, urban, and agricultura sources. Environ Sci Technol 2010:1947-53.

Thiele-Bruhn S. Pharmaceutical antibiotic compounds in soils - a review. J Plant Nutr Soil Sci 2003;166:145-67.

Wardwell L, Jude B, Moody J, Olcerst A, Gyure R, Nelson R, et al. Co-selection of mercury and antibiotic resistance in Sphagnum core samples dating back 2000 years. Geomicrobiol J 2009:351-60.

Watts RJ. Partitioning, sorption, and exchange at surfaces. Hazardous wastes: sources, pathways, receptors. New York: John Wiley \& Sons; 1998.

Zhang T, Zhang M, Zhang X, Fang HH. Tetracycline resistance genes and tetracycline resistant lactose-fermenting enterobacteriaceae in activated sludge of sewage treatment plants. Environ Sci Technol 2009;43:3455-60. 
Occurrence of Antimicrobials and Antimicrobial Resistance Genes in Beef Cattle Storage

Ponds and Swine Treatment Lagoons

Yuping Zhang ${ }^{\mathrm{a}}$, Chiqian Zhang ${ }^{\mathrm{a}, 1}$, David Parker ${ }^{\mathrm{b}, 2}$, Daniel D. Snow ${ }^{\mathrm{c}}$, Zhi Zhou ${ }^{\mathrm{d}}$ and Xu Li ${ }^{\mathrm{a},{ }^{*}}$

${ }^{a}$ Department of Civil Engineering, ${ }^{c}$ Water Sciences Laboratory, University of Nebraska-Lincoln, Lincoln, NE; ${ }^{\mathrm{b}}$ USDA Meat Animal Research Center, Clay Center, NE; ${ }^{\mathrm{d}}$ Department of Civil and Environmental Engineering, National University of Singapore, Singapore.

*Corresponding author:

844 N. 16th Street, N117 SLNK

Lincoln, NE 68588-6105

Phone: (402) 472-6042

Fax: (402) 472-8934

E-mail: $\underline{x u l i @ u n l . e d u ~}$

${ }^{1}$ Current address: Department of Civil and Environmental Engineering, University of MissouriColumbia, Columbia, MO;

${ }^{2}$ Current address: Palo Duro Reseach Center, West Texas A\&M University, Canyon, TX.

Supporting Information:

16 pages, 11 tables, and 2 figures. 


\section{Detailed Lagoon Description}

The beef cattle waste storage ponds were described previously (Parker et al., 1999). The feedlot was originally designed and constructed in 1974, at which time runoff from the feedlot drained to the south into a shallow sedimentation basin $(\mathrm{C} 1)$ then to pond $\mathrm{C} 2$. The feedlot was expanded to 3500 feeder cattle in 1989, at which time a third pond (C3) was added. A fourth pond (C4) was constructed in 2007 to add additional storage capacity. Each pond has sidewall slopes of $3 \mathrm{H}: 1 \mathrm{~V}$ and depth of 0.5 to $1.5 \mathrm{~m}$. In its present configuration, $\mathrm{C} 4$ was the terminal pond, where wastewater was pumped periodically and used to irrigate and fertilize a nearby alfalfa field. Water decants sequentially from one pond to the next through a drainage pipe located one meter above the bottom of each pond. Historically, the sludge and sediment in Pond C1 was cleaned every 5-10 years, while C2 and C3 were cleaned every 25 years. Pond C4 had been operational for 5 years and the sludge and sediment had never been cleaned.

The swine treatment lagoons received wastewater from 16 mechanically-ventilated barns that housed nursery pigs, feeder pigs, and breeding stock in separate barns. The pigs were fed a corn and soybean-based diet. All pigs were raised on elevated slatted floors, and manure was collected below the slats. The waste management system consisted of barns with either pull-plug or flush systems. In the flush barns, manure was flushed to the lagoons twice per day using clean water. In the pull-plug barns, the shallow pit was filled with clean water to a depth of $0.5 \mathrm{~m}$, and wastewater was drained to the lagoons once per week. Wastewater flowed by gravity through subsurface piping to three sequential treatment lagoons, designated as S1 to S3. The swine lagoons had total depths of about $3 \mathrm{~m}$. 
Table S-1. Depth of lagoons measured at two sampling events.

\begin{tabular}{ccc}
\hline Pond/Lagoon & Sep.2010 (m) & Jun.2011 (m) \\
\hline C1 & 0.6 & 0.4 \\
C2 & 1.5 & 1.5 \\
C3 & 0.9 & 1.1 \\
C4 & 0.6 & 1.0 \\
S1 & 2.7 & 3.1 \\
S2 & 2.0 & 2.1 \\
S3 & 2.9 & 2.7 \\
\hline
\end{tabular}


Table S-2. Antimicrobials measured with selected reaction monitoring transitions, cone voltages, collision energies, and expected retention times.

\begin{tabular}{|c|c|c|c|c|c|c|c|c|}
\hline Compound & CAS number & Formula & $\begin{array}{c}\text { MW } \\
\left(\mathrm{g} \mathrm{mol}^{-1}\right)\end{array}$ & $\begin{array}{c}\text { Parent } \\
\text { Ion } \\
(\mathrm{m} / \mathrm{z})\end{array}$ & $\begin{array}{c}\text { Product } \\
\text { Ion } \\
(\mathrm{m} / \mathrm{z})\end{array}$ & $\begin{array}{c}\text { Cone } \\
\text { Voltage } \\
\text { (V) }\end{array}$ & $\begin{array}{c}\text { Collision } \\
\text { Energy } \\
(\mathrm{eV})\end{array}$ & $\begin{array}{c}\text { Retention } \\
\text { time } \\
\text { (min) }\end{array}$ \\
\hline Chlortetracycline & $57-62-5$ & $\underline{\mathbf{C}}_{22} \underline{\mathbf{H}}_{23} \mathrm{Cl}_{2} \underline{\mathbf{N}}_{2} \underline{\mathbf{O}}_{8}$ & 478.88 & 478.9 & 444 & 28 & 20 & 12.84 \\
\hline Demeclocycline* & $127-33-3$ & $\underline{\mathbf{\mathbf { C }}}_{21} \underline{\mathbf{\mathbf { H }}}_{21} \mathrm{Cl} \underline{\mathbf{N}}_{2} \underline{\overline{\mathbf{O}}}_{8}$ & 464.853 & 464.9 & 447.9 & 27 & 17 & 12.14 \\
\hline Doxycycline** & $564-25-0$ & $\underline{\mathbf{C}}_{22} \underline{\mathbf{H}}_{24} \underline{\mathbf{N}}_{2} \underline{\mathbf{O}}_{8}$ & 444.435 & 445.05 & 428.05 & 29 & 19 & 13.65 \\
\hline Erythromycin & $114-07-8$ & $\underline{\mathbf{C}}_{37} \underline{\mathbf{H}}_{67} \underline{\mathbf{N O}}_{13}$ & 733.93 & 734 & 158 & 30 & 30 & 14.78 \\
\hline Isochlortetracycline & $514-53-4$ & $\underline{\mathbf{C}}_{22} \underline{\mathbf{H}}_{23} \mathrm{Cl}_{1} \underline{\mathbf{N}}_{2} \underline{\mathbf{O}}_{8}$ & 478.88 & 478.9 & 444 & 28 & 20 & 12.84 \\
\hline Lincomycin & $154-21-2$ & $\underline{\mathbf{C}}_{18} \underline{\mathbf{H}}_{34} \underline{\mathbf{N}}_{2} \underline{\mathbf{O}}_{6} \mathrm{~S}$ & 406.538 & 407 & 126 & 38 & 25 & 10.85 \\
\hline Monensin & $17090-79-8$ & $\underline{\mathbf{C}}_{36} \underline{\mathbf{H}}_{62} \underline{\mathbf{O}}_{11}$ & 670.871 & 688.1 & 635.15 & 22 & 17 & 22.04 \\
\hline (Sodium adduct) & & & & 693.1 & 675.1 & 50 & 38 & 22.04 \\
\hline Oxytetracycline & $79-57-2$ & $\underline{\mathbf{C}}_{22} \underline{\mathbf{H}}_{24} \underline{\mathbf{N}}_{2} \underline{\mathbf{O}}_{9}$ & 460.434 & 460.9 & 425.9 & 25 & 20 & 11.66 \\
\hline Sulfachloropyridazine & $80-32-0$ & $\underline{\mathbf{C}}_{10} \underline{\mathbf{H}}_{9} \mathrm{Cl}_{\underline{\mathbf{N}}_{4}} \underline{\mathbf{O}}_{2} \mathrm{~S}$ & 284.72 & 285 & 155.95 & 24 & 15 & 12.41 \\
\hline Sulfadimethoxine & $122-11-2$ & $\underline{\mathbf{C}}_{12} \underline{\mathbf{H}}_{14} \underline{\mathbf{N}}_{4} \underline{\mathbf{O}}_{4} \mathrm{~S}$ & 310.33 & 311.05 & 155.95 & 28 & 20 & 13.81 \\
\hline Sulfamerazine & $127-79-7$ & $\underline{\mathbf{C}}_{11} \underline{\mathbf{H}}_{12} \underline{\mathbf{N}}_{4} \underline{\mathbf{O}}_{2} \mathrm{~S}$ & 264.305 & 265.1 & 155.95 & 28 & 16 & 11.33 \\
\hline Sulfamethazine & $57-68-1$ & $\underline{\mathbf{C}}_{12} \underline{\mathbf{H}}_{14} \underline{\mathbf{N}}_{4} \underline{\mathbf{O}}_{2} \mathrm{~S}$ & 278.33 & 279.1 & 155.95 & 30 & 18 & 11.93 \\
\hline Sulfamethazine $\left({ }^{13} \mathrm{C}_{6}\right) *$ & ---------- & ${ }^{13} \underline{\mathbf{C}}_{6} \underline{\mathbf{C}}_{6} \underline{\mathbf{H}}_{14} \underline{\mathbf{N}}_{4} \underline{\mathbf{O}}_{2} \mathrm{~S}$ & 284.33 & 285.1 & 123.95 & 30 & 25 & 11.98 \\
\hline Sulfamethizole & $144-82-1$ & $\underline{\mathbf{C}}_{9} \underline{\mathbf{H}}_{10} \underline{\mathbf{N}}_{4} \underline{\mathbf{O}}_{2} \mathbf{S}_{2}$ & 270.333 & 271.05 & 155.95 & 24 & 13 & 10.85 \\
\hline Sulfamethoxazole & $723-46-6$ & $\underline{\mathbf{C}}_{10} \underline{\mathbf{H}}_{11} \underline{\mathbf{N}}_{3} \underline{\mathbf{O}}_{3} \mathrm{~S}$ & 253.279 & 254.1 & 155.95 & 23 & 15 & 12.41 \\
\hline Sulfathiazole & $72-14-0$ & $\underline{\mathbf{C}}_{9} \underline{\mathbf{H}}_{9} \underline{\mathbf{N}}_{3} \underline{\mathbf{O}}_{2} \mathrm{~S}_{2}$ & 255.319 & 256.05 & 155.95 & 25 & 14 & 10.85 \\
\hline Tetracycline & $60-54-8$ & $\underline{\mathbf{C}}_{22} \underline{\mathbf{H}}_{24} \underline{\mathbf{N}}_{2} \underline{\mathbf{O}}_{8}$ & 444.435 & 444.9 & 410.05 & 23 & 19 & 11.50 \\
\hline Tiamulin & $55297-95-5$ & $\underline{\mathbf{C}}_{28} \underline{\mathbf{H}}_{47} \underline{\mathbf{N O}}_{4} \mathbf{S}$ & 493.742 & 493.9 & 191.9 & 32 & 24 & 14.40 \\
\hline Tylosin & $1401-69-0$ & $\underline{\mathbf{C}}_{46} \underline{\mathbf{H}}_{77} \underline{\mathbf{N O}}_{17}$ & 916.10 & 916.9 & 174.2 & 50 & 35 & 14.78 \\
\hline Virginiamycin M1 & $11006-76-1$ & $\underline{\mathbf{C}}_{28} \underline{\mathbf{H}}_{35} \underline{\mathbf{N}}_{3} \underline{\mathbf{O}}_{7}$ & 525.6 & 526 & 355.1 & 24 & 18 & 17.04 \\
\hline
\end{tabular}

* Internal Standard

**Surrogate 
Table S-3. Sequence and PCR condition of the regular PCR primer sets used in the study.

\begin{tabular}{|c|c|c|c|c|c|}
\hline $\begin{array}{l}\text { Target } \\
\text { gene }\end{array}$ & Primer & Sequence (5'-3’) & $\begin{array}{l}\text { Target } \\
\text { size }(b p)\end{array}$ & $\begin{array}{l}\text { Annealing } \\
\text { temperature }\left({ }^{\circ} \mathrm{C}\right)\end{array}$ & Reference \\
\hline \multirow[t]{2}{*}{ sull } & sull-FW & CGC ACC GGA AAC ATC GCT GCA C & \multirow[t]{2}{*}{163} & \multirow[t]{2}{*}{55.9} & \multirow{2}{*}{$\begin{array}{l}\text { (Storteboom et } \\
\text { al., 2010) }\end{array}$} \\
\hline & sull-RV & TGA AGT TCC GCC GCA AGG CTC G & & & \\
\hline \multirow[t]{2}{*}{ sul2 } & sul2-FW & TCC GGT GGA GGC CGG TAT CTG G & \multirow[t]{2}{*}{191} & \multirow[t]{2}{*}{60.8} & \multirow{2}{*}{$\begin{array}{l}\text { (Storteboom et } \\
\text { al., 2010) }\end{array}$} \\
\hline & sul2-RV & CGG GAA TGC CAT CTG CCT TGA G & & & \\
\hline \multirow[t]{2}{*}{ tet $D$} & tetD-FW & AAA CCA TTA CGG CAT TCT GC & \multirow[t]{2}{*}{787} & \multirow[t]{2}{*}{55} & \multirow{2}{*}{ (Ng et al., 2001) } \\
\hline & tetD-RV & GAC CGG ATA CAC CAT CCA TC & & & \\
\hline \multirow[t]{2}{*}{ tetE } & tetE-FW & TCG GGA TTG TTA GTT GTC TTT TTC & \multirow[t]{2}{*}{549} & \multirow[t]{2}{*}{62} & \multirow{2}{*}{ (Fan et al., 2007) } \\
\hline & tetE-RV & GTG GAT TAC CCT ACC TGG ATG GA & & & \\
\hline \multirow[t]{2}{*}{ tetO } & tet $O-\mathrm{FW}$ & AAC TTA GGC ATT CTG GCT CAC & \multirow[t]{2}{*}{515} & \multirow[t]{2}{*}{55} & \multirow{2}{*}{ (Ng et al., 2001) } \\
\hline & tetO-RV & TCC CAC TGT TCC ATA TCG TCA & & & \\
\hline \multirow[t]{2}{*}{ tet $Q$} & tet $Q-\mathrm{FW}$ & AGAATCTGCTGTTTGCCAGTG & \multirow[t]{2}{*}{169} & \multirow[t]{2}{*}{63} & \multirow{4}{*}{$\begin{array}{l}\text { (Aminov et al., } \\
2001 \text { ) } \\
\text { (Ghosh et al., } \\
2009 \text { ) }\end{array}$} \\
\hline & tetQ-RV & CGGAGTGTCAATGATATTGCA & & & \\
\hline \multirow[t]{2}{*}{ tet $X$} & tet $X-\mathrm{FW}$ & AGC CTT ACC AAT GGG TGT AAA & \multirow[t]{2}{*}{278} & \multirow[t]{2}{*}{60} & \\
\hline & tetX-RV & TTC TTA CCT TGG ACA TCC CG & & & \\
\hline
\end{tabular}


Table S-4. Sequence and annealing temperature of the qPCR primer sets used in the study.

\begin{tabular}{|c|c|c|c|c|c|}
\hline Target gene & Primer & Sequence $\left(5^{\prime}-3^{\prime}\right)$ & $\begin{array}{l}\text { Target size } \\
\text { (bp) }\end{array}$ & $\begin{array}{c}\text { Annealing } \\
\text { temperature } \\
\left({ }^{\circ} \mathrm{C}\right)\end{array}$ & Ref. \\
\hline \multirow[t]{2}{*}{ sull } & sull-FW & CGC ACC GGA AAC ATC GCT GCA C & 163 & 65.0 & \multirow{2}{*}{ (Pei et al., 2006) } \\
\hline & sull-RV & TGA AGT TCC GCC GCA AGG CTC G & & & \\
\hline \multirow[t]{2}{*}{ sul2 } & sul2-FW & TCC GGT GGA GGC CGG TAT CTG G & 191 & 57.5 & \multirow{2}{*}{ (Pei et al., 2006) } \\
\hline & sul2-RV & CGG GAA TGC CAT CTG CCT TGA G & & & \\
\hline \multirow[t]{2}{*}{ tetD } & tet $D-F W$ & GAA TGC CTG CAC CTT TCT GAT G & 346 & 62 & \multirow{2}{*}{ (Fan et al., 2007) } \\
\hline & tetD-RV & GGC AATAAA TCC GGC GAA AA & & & \\
\hline \multirow[t]{2}{*}{ tetE } & tetE-FW & TCGGGATTG TTA GTT GTC TTT TTC & 549 & 58.51 & \multirow{2}{*}{ (Fan et al., 2007) } \\
\hline & tetE-RV & GTGGATTAC CCT ACC TGG ATG GA & & & \\
\hline \multirow[t]{2}{*}{ tetO } & tetO-FW & ACG GAR AGT TTA TTG TAT ACC & 171 & 50.3 & \multirow{2}{*}{$\begin{array}{l}\text { (Aminov et al., 2001 } \\
\text { Pei et al., 2006) }\end{array}$} \\
\hline & tetO-RV & TGG CGT ATC TAT AAT GTT GAC & & & \\
\hline \multirow[t]{2}{*}{ tet $Q$} & tet $Q-\mathrm{FW}$ & AGA ATC TGC TGT TTG CCA GTG & 169 & 63 & \multirow{2}{*}{ (Aminov et al., 2001) } \\
\hline & tetQ-RV & CGG AGT GTC AAT GAT ATT GCA & & & \\
\hline \multirow[t]{2}{*}{ tet $X$} & tet $X-\mathrm{FW}$ & AGC CTT ACC AAT GGG TGT AAA & 278 & 60 & \multirow{2}{*}{ (Ghosh et al., 2009) } \\
\hline & tet $X-\mathrm{RV}$ & TTC TTA CCT TGG ACA TCC CG & & & \\
\hline \multirow[t]{2}{*}{ 16S rRNA } & BACT1369F & CGG TGA ATA CGT TCY CGG & 133 & 56 & \multirow{2}{*}{ (Suzuki et al., 2000) } \\
\hline & PROK1492R & GGW TAC CTT GTT ACG ACT T & & & \\
\hline
\end{tabular}


Table S-5. Major water quality parameters measured at the first sampling event in September 2010. C1-C4 and S1-S3 represent cattle storage ponds and swine treatment lagoons, while "S" and "B" represent surface water and bottom water samples.

\begin{tabular}{ccccccccccc}
\hline Sample ID & $\begin{array}{c}\mathrm{T} \\
\left({ }^{\circ} \mathrm{C}\right)\end{array}$ & $\begin{array}{c}\mathrm{COD} \\
(\mathrm{mg} / \mathrm{L})\end{array}$ & $\begin{array}{c}\left.\mathrm{NH}_{3}-\mathrm{N} / \mathrm{L}\right) \\
(\mathrm{mg})\end{array}$ & $\begin{array}{c}\mathrm{NO}_{2}{ }^{-} / \mathrm{NO}_{3}{ }^{-}-\mathrm{N} \\
(\mathrm{mg} / \mathrm{L})\end{array}$ & $\begin{array}{c}\text { Ortho-P } \\
(\mathrm{mg} / \mathrm{L})\end{array}$ & $\begin{array}{c}\mathrm{TP} \\
(\mathrm{mg} / \mathrm{L})\end{array}$ & $\begin{array}{c}\mathrm{SO}_{4}{ }^{2-} \\
(\mathrm{mg} / \mathrm{L})\end{array}$ & $\begin{array}{c}\mathrm{Zn} \\
(\mu \mathrm{g} / \mathrm{L})\end{array}$ & $\begin{array}{c}\mathrm{Cu} \\
(\mu \mathrm{g} / \mathrm{L})\end{array}$ & $\begin{array}{c}\text { Conductivity } \\
\square(\mu \mathrm{S} / \mathrm{cm})\end{array}$ \\
\hline $\mathrm{C} 1-\mathrm{S}$ & 21.27 & 1400 & 23.9 & 13.5 & 7.64 & 21.8 & 377.6 & 20.4 & 64.9 & 6612 \\
$\mathrm{C} 2-\mathrm{S}$ & 18.16 & 1200 & 43.1 & 6.61 & 7.00 & 19.1 & 134.8 & 16.2 & 28.8 & 4760 \\
$\mathrm{C} 2-\mathrm{B}$ & 20.53 & 1100 & 33.4 & 5.14 & 7.31 & 18.6 & 145.6 & 13.3 & 34.5 & 4723 \\
$\mathrm{C} 3-\mathrm{S}$ & 19.15 & 1300 & 13.5 & 0.20 & 7.50 & 24.3 & 54.6 & 8.8 & 13.4 & 4192 \\
$\mathrm{C} 4-\mathrm{S}$ & 18.54 & 1200 & 0.1 & 5.06 & 9.30 & 28.6 & 28.9 & 5.5 & 17.0 & 4185 \\
$\mathrm{~S} 1-\mathrm{S}$ & 22.12 & 300 & 104.0 & $<0.05$ & 5.86 & 10.4 & 40.9 & 2.8 & 1.3 & 1718 \\
$\mathrm{~S} 1-\mathrm{B}$ & 21.05 & 5300 & 117.0 & $<0.05$ & 6.94 & 24.5 & 40.4 & 22.3 & $<0.5$ & 1732 \\
$\mathrm{~S} 2-\mathrm{S}$ & 23.51 & 100 & 2.1 & 2.37 & 3.38 & 10.2 & 20.3 & 2.6 & 1.9 & 876 \\
$\mathrm{~S} 2-\mathrm{B}$ & 19.30 & 1100 & 5.9 & 2.84 & 3.75 & 12.3 & 28.8 & 1.3 & $<0.5$ & 930 \\
$\mathrm{~S} 3-\mathrm{S}$ & 21.73 & 400 & 97.1 & $<0.05$ & 5.44 & 15.2 & 41.8 & 1.7 & 9.2 & 1728 \\
$\mathrm{~S} 3-\mathrm{B}$ & 20.40 & 700 & 105.0 & $<0.05$ & 5.06 & 11.8 & 41.5 & 8.3 & $<0.5$ & 1761 \\
\hline
\end{tabular}


Table S-6. Major water quality parameters measured at the second sampling event in June 2011. C1-C4 and S1-S3 represent cattle storage ponds and swine treatment lagoons, while " $\mathrm{S}$ " and " $\mathrm{B}$ " represent surface water and bottom water samples.

\begin{tabular}{|c|c|c|c|c|c|c|c|c|c|c|c|c|c|}
\hline Sample ID & $\begin{array}{c}\mathrm{T} \\
\left({ }^{\circ} \mathrm{C}\right) \\
\end{array}$ & $\mathrm{pH}$ & $\begin{array}{c}\mathrm{DO} \\
(\mathrm{mg} / \mathrm{L})\end{array}$ & $\begin{array}{c}\mathrm{COD} \\
(\mathrm{mg} / \mathrm{L})\end{array}$ & $\begin{array}{l}\mathrm{NH}_{3}-\mathrm{N} \\
(\mathrm{mg} / \mathrm{L})\end{array}$ & $\begin{array}{c}\mathrm{NO}_{2}{ }^{-} / \mathrm{NO}_{3}{ }^{-}-\mathrm{N} \\
(\mathrm{mg} / \mathrm{L})\end{array}$ & $\begin{array}{l}\begin{array}{c}\text { Ortho-P } \\
(\mathrm{mg} / \mathrm{L})\end{array} \\
\end{array}$ & $\begin{array}{c}\mathrm{TP} \\
(\mathrm{mg} / \mathrm{L})\end{array}$ & $\begin{array}{c}\mathrm{SO}_{4}{ }^{2-} \\
(\mathrm{mg} / \mathrm{L})\end{array}$ & $\begin{array}{c}\mathrm{Zn} \\
(\mu \mathrm{g} / \mathrm{L}) \\
\end{array}$ & $\begin{array}{c}\mathrm{Cu} \\
(\mu \mathrm{g} / \mathrm{L}) \\
\end{array}$ & $\begin{array}{l}\text { ORP } \\
\mathrm{mV}\end{array}$ & $\begin{array}{c}\text { Conductivity } \\
\mu \mathrm{S} / \mathrm{cm}\end{array}$ \\
\hline C1-S & 24.8 & 9.22 & 0.03 & 2083 & 29.8 & 0.25 & 15.2 & 35.6 & 2.91 & 27.4 & 23.6 & -224.8 & 3713 \\
\hline C2-S & 23.7 & 8.40 & 0.44 & 2232 & 44.8 & 0.13 & 16.7 & 21.0 & 3.25 & 25.9 & 27.6 & -174.4 & 3744 \\
\hline C2-B & 22.9 & 8.45 & 0.33 & 2228 & 40.7 & 0.32 & 11.7 & 34.7 & 2.39 & 39.1 & 32.4 & -224.1 & 3713 \\
\hline C3-S & 23.7 & 8.52 & 0.04 & 2176 & 20.0 & 0.24 & 15.3 & 47.3 & 6.82 & 28.1 & 26.5 & -207.9 & 3988 \\
\hline C4-S & 23.9 & 8.46 & 0.11 & 1808 & 7.1 & 0.20 & 16.5 & 24.7 & 23.7 & 23.7 & 24.5 & -124.1 & 4117 \\
\hline S1-S & 24.6 & 8.61 & 0.04 & 360 & 135.0 & 0.08 & 5.05 & 62.3 & 27.6 & 5.5 & 2.5 & -117.1 & 1809 \\
\hline S1-B & 24.6 & 8.51 & 0.01 & 4870 & 127.0 & $<0.05$ & 2.84 & 48.2 & 22.3 & 6.6 & 1.3 & -185.0 & 1622 \\
\hline S2-S & 24.7 & 8.73 & 3.27 & 191 & 101.0 & 0.11 & 3.80 & 16.4 & 25.9 & 1.4 & 1.8 & 19.8 & 1617 \\
\hline S2-B & 22.9 & 8.20 & 0.03 & 212 & 112.0 & 0.09 & 3.23 & 16.8 & 27.0 & 3.3 & 1.2 & -138.6 & 1743 \\
\hline S3-S & 24.3 & 8.90 & 4.04 & 146 & 72.0 & $<0.05$ & 3.74 & 21.8 & 34.3 & 3.9 & $<0.5$ & 31.0 & 1391 \\
\hline S3-B & 21.5 & 9.00 & 0.03 & 218 & 74.7 & $<0.05$ & 3.32 & 37.4 & 22.6 & 3.6 & $<0.5$ & -216.2 & 1361 \\
\hline
\end{tabular}


Table S-7. Antimicrobial concentrations in water samples $(\mu \mathrm{g} / \mathrm{L})$. The first row under each sample ID report results from the first sampling event in September 2010 and the second row reports results from the second sampling event in June 2011.

\begin{tabular}{|c|c|c|c|c|c|c|c|c|c|c|c|c|c|c|c|c|}
\hline Sample ID & 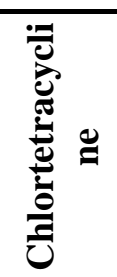 & 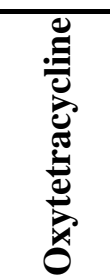 & & 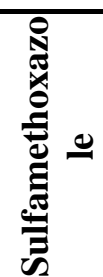 & 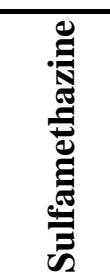 & 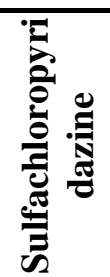 & 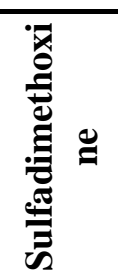 & 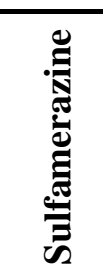 & 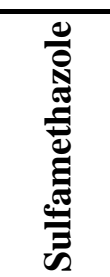 & 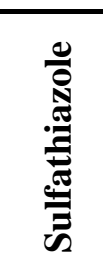 & 芯 & $\frac{B}{3}$ & 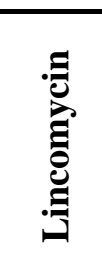 & 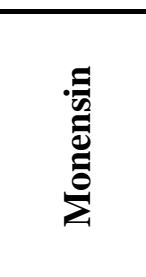 & & 胥 \\
\hline \multirow[t]{2}{*}{ C1-S } & $\mathrm{ND}^{1}$ & ND & 0.569 & $\mathrm{ND}$ & ND & ND & 0.089 & ND & ND & ND & ND & ND & ND & 150.400 & ND & ND \\
\hline & 0.419 & ND & ND & ND & 0.026 & ND & 0.056 & ND & ND & ND & 0.071 & 0.040 & ND & 86.501 & 0.613 & ND \\
\hline \multirow{2}{*}{$\mathrm{C} 2-\mathrm{S}$} & ND & ND & ND & ND & ND & ND & 0.547 & ND & ND & ND & 0.455 & ND & ND & 176.800 & ND & ND \\
\hline & 0.373 & ND & ND & ND & ND & ND & 0.036 & ND & ND & ND & 0.037 & ND & ND & 117.152 & 0.807 & ND \\
\hline \multirow[t]{2}{*}{ C2-B } & ND & ND & ND & ND & ND & ND & 0.084 & ND & ND & ND & ND & ND & ND & 307.800 & ND & ND \\
\hline & 0.303 & ND & ND & ND & ND & ND & 0.027 & ND & ND & ND & 0.012 & ND & ND & 83.901 & 1.266 & ND \\
\hline \multirow[t]{2}{*}{ C3-S } & ND & ND & ND & ND & ND & ND & ND & ND & ND & ND & ND & ND & ND & 45.300 & ND & ND \\
\hline & ND & ND & ND & ND & ND & ND & 0.042 & ND & ND & ND & 0.013 & ND & ND & 101.208 & 1.226 & ND \\
\hline \multirow[t]{2}{*}{ C4-S } & 2.005 & 1.471 & 1.843 & ND & 0.342 & 0.431 & 0.586 & ND & 0.452 & 0.130 & 0.202 & ND & ND & ND & ND & ND \\
\hline & ND & ND & ND & ND & ND & ND & 0.035 & ND & ND & ND & 0.027 & ND & ND & 123.022 & 0.234 & ND \\
\hline \multirow[t]{2}{*}{ S1-S } & 2.743 & 2.138 & 2.860 & ND & 0.267 & 0.289 & 0.179 & ND & 0.213 & 0.135 & ND & 0.845 & ND & $\mathrm{N} / \mathrm{A}^{2}$ & ND & ND \\
\hline & 1.532 & 0.010 & 0.425 & 0.220 & 0.433 & 0.283 & 0.404 & 0.414 & 0.351 & 0.444 & 0.762 & 0.638 & 0.517 & 0.776 & 0.443 & 0.808 \\
\hline \multirow[t]{2}{*}{ S1-B } & ND & ND & ND & ND & ND & ND & ND & ND & ND & ND & ND & ND & 0.367 & N/A & ND & ND \\
\hline & 0.990 & ND & 0.334 & 0.235 & 0.416 & 0.296 & 0.443 & 0.397 & 0.350 & 0.438 & 0.659 & 0.587 & 0.333 & 0.895 & 0.205 & 0.877 \\
\hline \multirow[t]{2}{*}{ S2-S } & ND & ND & ND & 0.104 & 0.275 & 0.178 & 0.196 & 0.335 & 0.424 & 0.193 & 1.484 & ND & ND & N/A & ND & ND \\
\hline & 0.350 & ND & 0.218 & 0.342 & 0.574 & 0.443 & 0.548 & 0.548 & 0.490 & 0.540 & 0.889 & 0.505 & 0.484 & 0.764 & 1.592 & 0.682 \\
\hline \multirow[t]{2}{*}{ S2-B } & ND & ND & ND & 0.212 & 0.410 & 0.376 & 0.460 & 0.415 & 0.321 & 0.402 & 3.636 & ND & ND & N/A & ND & ND \\
\hline & ND & ND & ND & ND & ND & ND & ND & ND & ND & ND & 0.240 & ND & 0.011 & 0.857 & 0.379 & ND \\
\hline \multirow[t]{2}{*}{ S3-S } & 0.343 & 0.394 & 0.467 & ND & ND & ND & ND & ND & ND & ND & 0.138 & 4.913 & 0.208 & N/A & ND & ND \\
\hline & ND & ND & & ND & ND & ND & ND & ND & ND & ND & ND & ND & $\mathrm{ND}$ & 0.725 & 0.246 & ND \\
\hline \multirow[t]{2}{*}{ S3-B } & ND & 0.125 & 0.147 & ND & 0.092 & 0.062 & ND & ND & ND & ND & ND & ND & ND & N/A & ND & ND \\
\hline & ND & ND & ND & ND & ND & ND & ND & ND & ND & ND & ND & ND & ND & 0.705 & 0.146 & ND \\
\hline
\end{tabular}

${ }^{1} \mathrm{ND}=$ not detected. The detection limits were $0.050 \mu \mathrm{g} / \mathrm{L}$ and $0.010 \mu \mathrm{g} / \mathrm{L}$ for samples from the first and the second sampling events, respectively.

${ }^{2} \mathrm{~N} / \mathrm{A}=$ not available. Monensin was not measured for swine lagoons samples collected in the first sampling event. 
Table S-8. Antimicrobial concentrations in sludge samples $(\mu \mathrm{g} / \mathrm{kg})$. The first row under each sample ID report results from the first sampling event in September 2010 and the second row reports results from the second sampling event in June 2011. Erythromycin, sulfamethoxazole, sulfamethazole, sulfathiazole and virginiamycin were not included in the table as their concentrations were below MDL in all sludge samples.

\begin{tabular}{|c|c|c|c|c|c|c|c|c|c|c|c|c|c|}
\hline Sample-ID & 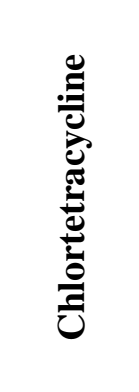 & 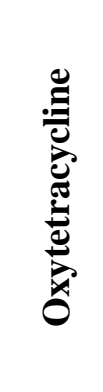 & 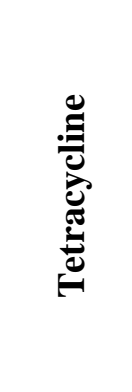 & 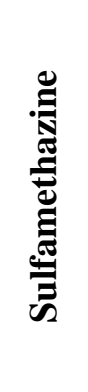 & 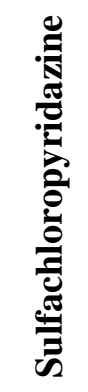 & 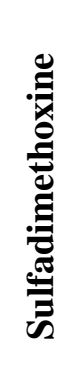 & 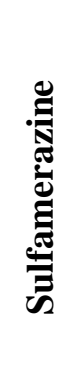 & 鸹 & $\frac{\sqrt{0}}{\overrightarrow{0}}$ & 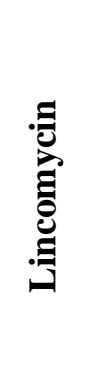 & 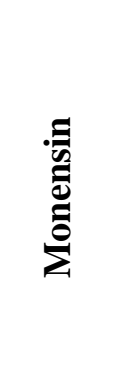 & 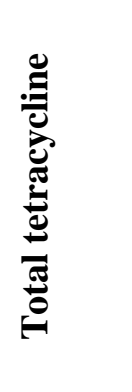 & 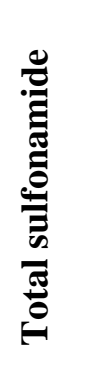 \\
\hline \multirow[t]{2}{*}{$\mathrm{C} 1$} & 189.5 & 4.6 & 59.4 & 2.1 & $\mathrm{ND}^{1}$ & 0.9 & ND & ND & ND & ND & 44.0 & 253.5 & 3.0 \\
\hline & 204.3 & 2.6 & 28.7 & 0.7 & ND & ND & ND & ND & 0.8 & ND & 41.4 & 235.6 & 0.7 \\
\hline \multirow{2}{*}{$\mathrm{C} 2$} & 1045.5 & 13.4 & 545.8 & 1.8 & ND & 0.9 & ND & ND & ND & ND & 107.6 & 1604.7 & 2.7 \\
\hline & 771.6 & 24.6 & 154.6 & 1.6 & 1.3 & 0.5 & ND & ND & 0.5 & ND & 297.1 & 950.8 & 3.4 \\
\hline \multirow[t]{2}{*}{$\mathrm{C} 3$} & 285.5 & 4.6 & 153.3 & 2.6 & ND & 1.2 & ND & ND & ND & ND & 30.8 & 443.4 & 3.8 \\
\hline & 535.9 & 9.5 & 113.4 & 6.3 & 1.2 & 3.4 & ND & ND & 0.6 & ND & 254.0 & 658.8 & 10.9 \\
\hline \multirow[t]{2}{*}{$\mathrm{C} 4$} & 34.3 & 1.9 & 14.3 & 1.4 & ND & 1.1 & 0.6 & ND & ND & ND & 6.2 & 50.5 & 3.1 \\
\hline & 187.1 & 2.9 & 41.1 & 1.8 & 1.2 & 1.1 & ND & ND & 0.6 & ND & 137.0 & 231.1 & 4.1 \\
\hline \multirow[t]{2}{*}{ S1 } & 7218.4 & 65.6 & 1623.8 & ND & ND & ND & 0.9 & 12.8 & 27.4 & 4.4 & ND & 8907.8 & 0.9 \\
\hline & 2674.0 & 16.0 & 291.8 & ND & ND & ND & ND & 24.9 & 170.4 & 2.5 & 17.5 & 2981.8 & ND \\
\hline \multirow[t]{2}{*}{ S2 } & 5619.0 & 32.6 & 1057.8 & 0.4 & ND & ND & ND & 5.0 & 15.9 & ND & ND & 6709.4 & 0.4 \\
\hline & 1847.2 & 14.6 & 149.6 & ND & ND & ND & ND & 26.5 & 79.5 & 1.4 & 8.2 & 2011.4 & ND \\
\hline \multirow[t]{2}{*}{ S3 } & 1370.8 & 7.7 & 191.8 & 0.4 & ND & ND & ND & 1.2 & 4.0 & 1.3 & ND & 1570.3 & 0.4 \\
\hline & 1089.9 & 8.4 & 90.2 & ND & ND & ND & ND & 8.1 & 14.1 & 3.0 & 2.7 & 1188.5 & ND \\
\hline
\end{tabular}

${ }^{1} \mathrm{ND}=$ not detected. The detection limit was $0.5 \mu \mathrm{g} / \mathrm{kg}$. 
Table S-9. Summary of DNA extraction and qPCR validation for selected ARGs.

\begin{tabular}{|c|c|c|c|c|c|c|c|}
\hline$\overline{\mathrm{ARG}}$ & $\begin{array}{l}\text { Amplificatio } \\
\mathrm{n} \text { efficiency }\end{array}$ & $\begin{array}{l}\text { Quantitation } \\
\text { range } \\
(\text { copies } / \mu \mathrm{L})\end{array}$ & $\begin{array}{l}\text { Spiked } \\
\text { copies } / \mu \mathrm{L}\end{array}$ & $\begin{array}{l}\text { Sampl } \\
\text { e }\end{array}$ & $\begin{array}{l}\text { Backgroun } \\
\mathrm{d} \\
\text { copies/ } \mu \mathrm{L}\end{array}$ & $\begin{array}{l}\text { Recovere } \\
\mathrm{d} \\
\text { copies } / \mu \\
\mathrm{L}\end{array}$ & $\begin{array}{l}\text { Recover } \\
\text { y rate } \\
(\%)\end{array}$ \\
\hline \multirow[t]{4}{*}{ sul2 } & 0.91 & $10^{2}-10^{8}$ & $4.68 \times 10^{8}$ & B1-S & $4.46 \times 10^{6}$ & $3.22 \times 10^{8}$ & 69.7 \\
\hline & & & & S2-B & $3.37 \times 10^{6}$ & $3.15 \times 10^{8}$ & 68.1 \\
\hline & & & & $\mathrm{B} 1$ & $7.13 \times 10^{5}$ & $4.25 \times 10^{8}$ & 91.1 \\
\hline & & & & S2 & $1.45 \times 10^{7}$ & $3.47 \times 10^{8}$ & 77.4 \\
\hline \multirow[t]{4}{*}{ tetD } & 0.72 & $10^{3}-10^{9}$ & $5.16 \times 10^{4}$ & B1-S & $\mathrm{ND}^{1}$ & $6.26 \times 10^{4}$ & 122.3 \\
\hline & & & & S2-B & ND & $7.78 \times 10^{4}$ & 151.8 \\
\hline & & & & B1 & ND & $5.84 \times 10^{4}$ & 114.3 \\
\hline & & & & $\mathrm{S} 2$ & ND & $1.08 \times 10^{5}$ & 210.7 \\
\hline \multirow[t]{4}{*}{ tet $Q$} & 0.93 & $10^{2}-10^{9}$ & $1.43 \times 10^{8}$ & B1-S & $4.25 \times 10^{6}$ & $8.73 \times 10^{7}$ & 71.6 \\
\hline & & & & S2-B & $5.04 \times 10^{6}$ & $1.22 \times 10^{8}$ & 90.5 \\
\hline & & & & B1 & $2.56 \times 10^{6}$ & $1.17 \times 10^{8}$ & 79.1 \\
\hline & & & & $\mathrm{S} 2$ & $2.85 \times 10^{6}$ & $1.94 \times 10^{8}$ & 108.5 \\
\hline \multirow[t]{4}{*}{ tet $X$} & 0.78 & $10^{3}-10^{8}$ & $3.41 \times 10^{5}$ & B 1-S & $3.37 \times 10^{4}$ & $1.20 \times 10^{6}$ & 353.0 \\
\hline & & & & S2-B & $1.54 \times 10^{4}$ & $1.07 \times 10^{6}$ & 314.1 \\
\hline & & & & B1 & $3.14 \times 10^{3}$ & $8.03 \times 10^{5}$ & 236.1 \\
\hline & & & & $\mathrm{S} 2$ & $6.94 \times 10^{3}$ & $1.31 \times 10^{6}$ & 383.7 \\
\hline
\end{tabular}

${ }^{1} \mathrm{ND}$, not detected. 
Table S-10. Correlations between ARGs and antimicrobials in water. Antimicrobials that were detected in less than 6 water samples were not included in this analysis.

\begin{tabular}{lcccccccccc} 
& & & \multicolumn{1}{c}{$r$} & & & \multicolumn{3}{c}{$p$-value } \\
& sull & sul2 & tetO & tetQ & tet $X$ & sull & sul2 & tetO & tetQ & tetX \\
\hline Total tetracycline & -0.13 & 0.10 & 0.36 & 0.36 & $\mathbf{0 . 6 1}$ & 0.573 & 0.651 & 0.104 & 0.099 & $\mathbf{0 . 0 0 3}$ \\
Total sulfonamide & 0.22 & $\mathbf{0 . 4 5}$ & 0.19 & 0.27 & 0.07 & 0.329 & $\mathbf{0 . 0 3 6}$ & 0.388 & 0.224 & 0.763 \\
Chlortetracycline & -0.05 & 0.24 & 0.36 & $\mathbf{0 . 4 2}$ & $\mathbf{0 . 4 8}$ & 0.837 & 0.272 & 0.100 & $\mathbf{0 . 0 4 9}$ & $\mathbf{0 . 0 2 2}$ \\
Tetracycline & -0.16 & 0.05 & 0.35 & 0.34 & $\mathbf{0 . 6 7}$ & 0.474 & 0.840 & 0.112 & 0.123 & $\mathbf{0 . 0 0 1}$ \\
Sulfamethazine & 0.24 & $\mathbf{0 . 4 6}$ & 0.26 & 0.34 & 0.16 & 0.287 & $\mathbf{0 . 0 3 1}$ & 0.241 & 0.124 & 0.485 \\
Sulfachloropyridazine & 0.14 & 0.36 & 0.25 & 0.29 & 0.22 & 0.541 & 0.101 & 0.261 & 0.184 & 0.327 \\
Sulfadimethoxine & 0.00 & 0.29 & 0.03 & 0.08 & 0.00 & 0.985 & 0.187 & 0.907 & 0.712 & 0.990 \\
Sulfamethazole & 0.15 & 0.30 & 0.15 & 0.19 & 0.07 & 0.518 & 0.173 & 0.511 & 0.401 & 0.768 \\
Sulfathiazole & 0.31 & $\mathbf{0 . 5 5}$ & 0.26 & 0.36 & 0.07 & 0.167 & $\mathbf{0 . 0 0 8}$ & 0.248 & 0.098 & 0.750 \\
Erythromycin & 0.45 & 0.08 & -0.25 & -0.17 & -0.35 & 0.035 & 0.731 & 0.253 & 0.440 & 0.110 \\
Lincomycin & 0.42 & $\mathbf{0 . 5 7}$ & $\mathbf{0 . 5 3}$ & $\mathbf{0 . 5 5}$ & 0.07 & 0.052 & $\mathbf{0 . 0 0 5}$ & $\mathbf{0 . 0 1 1}$ & $\mathbf{0 . 0 0 7}$ & 0.755 \\
Monensin & $\mathbf{0 . 5 9}$ & -0.41 & -0.51 & -0.37 & 0.16 & $\mathbf{0 . 0 1 6}$ & 0.117 & 0.045 & 0.156 & 0.555 \\
Tiamulin & -0.01 & 0.26 & 0.08 & 0.09 & -0.01 & 0.961 & 0.247 & 0.717 & 0.679 & 0.970 \\
Tylosin & 0.14 & 0.14 & 0.28 & 0.19 & 0.18 & 0.522 & 0.525 & 0.203 & 0.395 & 0.418 \\
\hline
\end{tabular}


Table S-11. Correlations between ARGs and antimicrobials in sludge. Antimicrobials that were detected in less than 6 sludge samples were not included in this analysis.

\begin{tabular}{lcccccccccc}
\hline & & \multicolumn{4}{c}{$r$} & & \multicolumn{4}{c}{$p$-value } \\
& sul1 & sul2 & tetO & tetQ & tet $X$ & sul1 & sul2 & tetO & tetQ & tet $X$ \\
\hline Total tetracycline & $\mathbf{0 . 5 5}$ & 0.52 & $\mathbf{0 . 8 4}$ & 0.50 & 0.11 & $\mathbf{0 . 0 4 3}$ & 0.059 & $\mathbf{0 . 0 0 0}$ & 0.068 & 0.699 \\
Total sulfonamide & -0.52 & $\mathbf{- 0 . 5 6}$ & -0.48 & -0.43 & -0.24 & 0.057 & $\mathbf{0 . 0 3 5}$ & 0.084 & 0.124 & 0.407 \\
Chlortetracycline & $\mathbf{0 . 5 8}$ & $\mathbf{0 . 5 5}$ & $\mathbf{0 . 8 6}$ & 0.52 & 0.14 & $\mathbf{0 . 0 2 8}$ & $\mathbf{0 . 0 4 0}$ & $\mathbf{0 . 0 0 0}$ & 0.059 & 0.632 \\
Oxytetracycline & 0.37 & 0.35 & $\mathbf{0 . 7 4}$ & 0.43 & 0.02 & 0.187 & 0.223 & $\mathbf{0 . 0 0 3}$ & 0.122 & 0.942 \\
Tetracycline & 0.35 & 0.32 & $\mathbf{0 . 7 3}$ & 0.41 & -0.01 & 0.224 & 0.265 & $\mathbf{0 . 0 0 3}$ & 0.144 & 0.961 \\
Sulfamethazine & -0.53 & $\mathbf{- 0 . 5 6}$ & -0.52 & -0.43 & -0.24 & 0.052 & $\mathbf{0 . 0 3 8}$ & 0.058 & 0.127 & 0.412 \\
Sulfadimethoxine & -0.49 & $\mathbf{- 0 . 5 5}$ & -0.48 & -0.41 & -0.20 & 0.074 & $\mathbf{0 . 0 4 2}$ & 0.086 & 0.141 & 0.489 \\
Tiamulin & $\mathbf{0 . 8 5}$ & $\mathbf{0 . 7 8}$ & $\mathbf{0 . 7 2}$ & $\mathbf{0 . 5 9}$ & $\mathbf{0 . 5 9}$ & $\mathbf{0 . 0 0 0}$ & $\mathbf{0 . 0 0 1}$ & $\mathbf{0 . 0 0 3}$ & $\mathbf{0 . 0 2 5}$ & $\mathbf{0 . 0 2 5}$ \\
Tylosin & $\mathbf{0 . 8 0}$ & $\mathbf{0 . 6 7}$ & $\mathbf{0 . 7 1}$ & $\mathbf{0 . 7 3}$ & $\mathbf{0 . 8 9}$ & $\mathbf{0 . 0 0 1}$ & $\mathbf{0 . 0 0 9}$ & $\mathbf{0 . 0 0 5}$ & $\mathbf{0 . 0 0 3}$ & $\mathbf{0 . 0 0 0}$ \\
Monensin & -0.38 & -0.40 & -0.44 & -0.37 & -0.15 & 0.179 & 0.159 & 0.117 & 0.194 & 0.606 \\
\hline
\end{tabular}



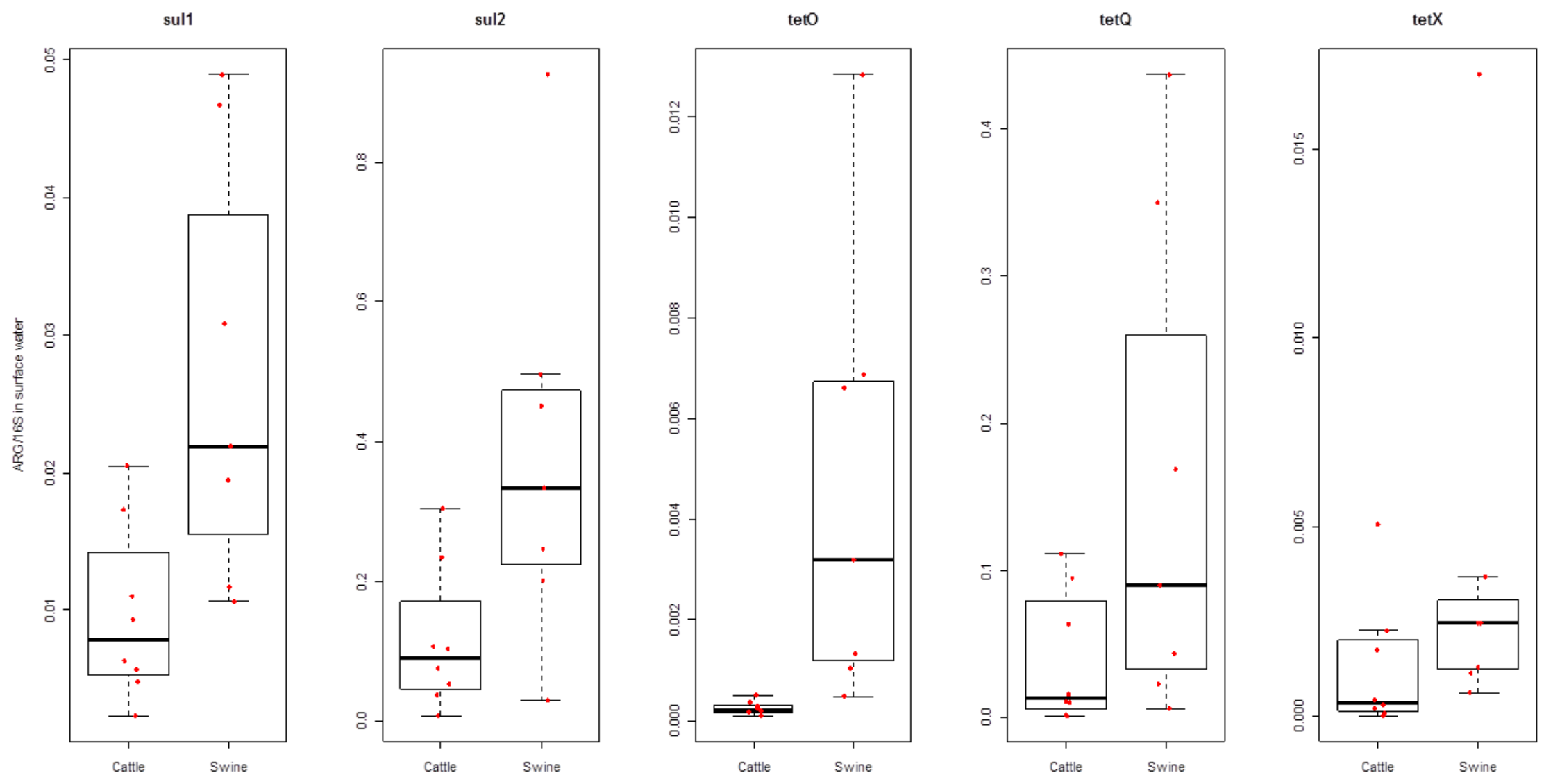

Figure S-1. Comparison of the relative abundance of ARGs in surface water between cattle ponds and swine lagoons. T-tests showed sull, sul 2 and tetO in cattle ponds were significantly lower than those in swine lagoons $(p<0.05)$. 

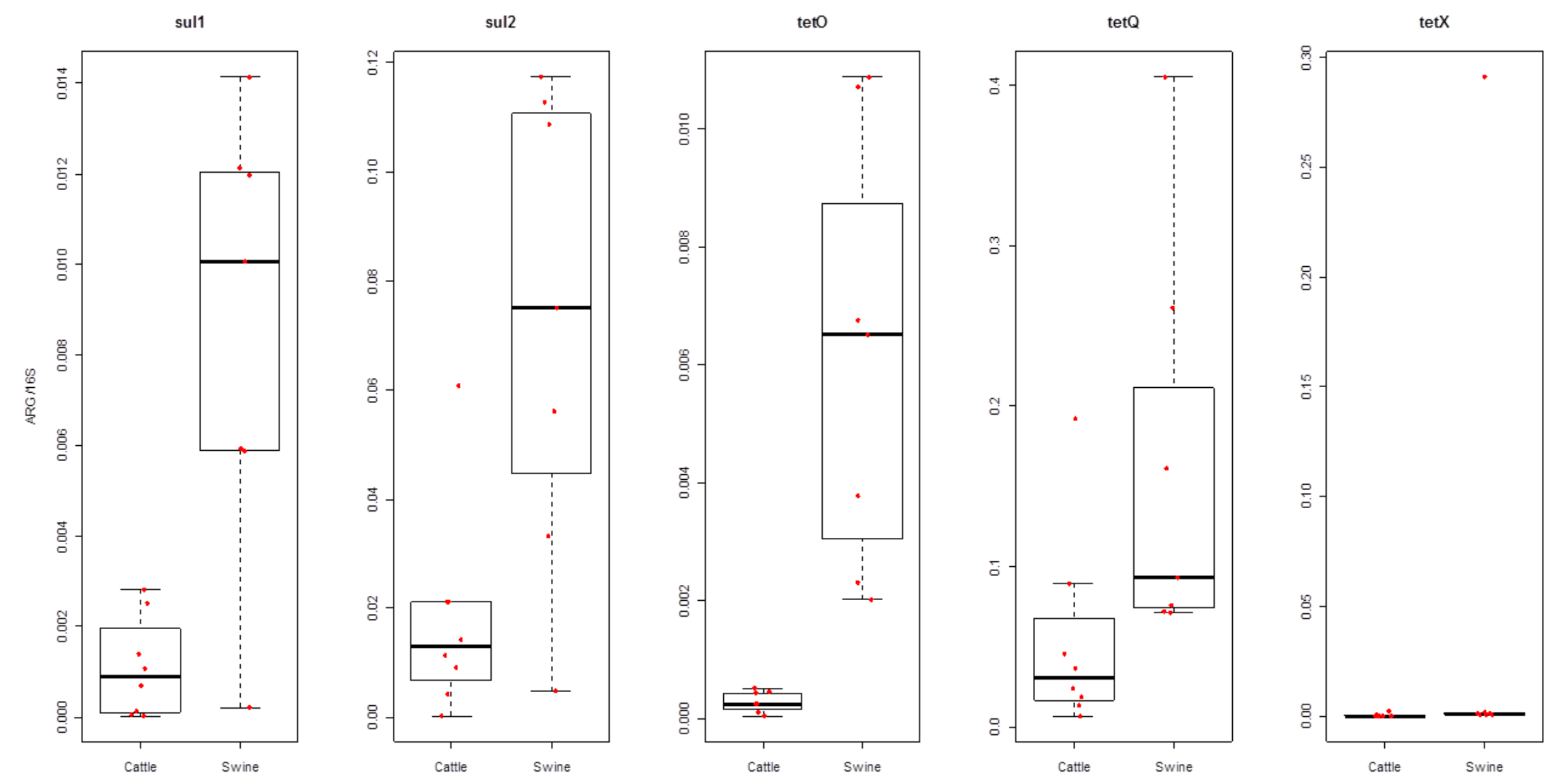

Figure S-2. Comparison of the relative abundance of ARGs in sludge between cattle ponds and swine lagoons. T-tests shows sull, sul2 and tet $O$ in cattle ponds were significantly lower than those in swine lagoons $(p<0.05)$. 


\section{References}

Aminov R, Garrigues-Jeanjean N, Mackie R. Molecular ecology of tetracycline resistance: Development and validation of primers for detection of tetracycline resistance genes encoding ribosomal protection proteins. Applied and Environmental Microbiology 2001: 22-32.

Fan W, Hamilton T, Webster-Sesay S, Nikolich M, Lindler L. Multiplex real-time SYBR Green IPCR assay for detection of tetracycline efflux genes of Gram-negative bacteria. Molecular and Cellular Probes 2007: 245-256.

Ghosh S, Ramsden S, LaPara T. The role of anaerobic digestion in controlling the release of tetracycline resistance genes and class 1 integrons from municipal wastewater treatment plants. Applied Microbiology and Biotechnology 2009: 791-796.

$\mathrm{Ng}$ L, Martin I, Alfa M, Mulvey M. Multiplex PCR for the detection of tetracycline resistant genes. Molecular and Cellular Probes 2001: 209-215.

Parker DB, Eisenhauer DE, Schulte DD, Nienaber JA. Seepage characteristics and hydraulic properties of a feedlot runoff storage pond. 1999.

Pei R, Kim S, Carlson K, Pruden A. Effect of River Landscape on the sediment concentrations of antibiotics and corresponding antibiotic resistance genes (ARG). Water Research 2006; 40: 2427-2435.

Storteboom H, Arabi M, Davis J, Crimi B, Pruden A. Identification of Antibiotic-ResistanceGene Molecular Signatures Suitable as Tracers of Pristine River, Urban, and Agricultural Sources. Environmental Science \& Technology 2010: 1947-1953.

Suzuki M, Taylor L, DeLong E. Quantitative analysis of small-subunit rRNA genes in mixed microbial populations via 5 '-nuclease assays. Applied and Environmental Microbiology 2000: 4605-4614. 